$9-4-2020$

\title{
Genocide and the Hispanic-American Dilemma
}

\author{
Eitan Ginzberg \\ University of Tel Aviv
}

Follow this and additional works at: https://digitalcommons.usf.edu/gsp

\section{Recommended Citation}

Ginzberg, Eitan (2020) "Genocide and the Hispanic-American Dilemma," Genocide Studies and Prevention: An International Journal: Vol. 14: Iss. 2: 122-152.

DOI:

https://doi.org/10.5038/1911-9933.14.2.1666

Available at: https://digitalcommons.usf.edu/gsp/vol14/iss2/10

This Articles is brought to you for free and open access by the Open Access Journals at Digital Commons @ University of South Florida. It has been accepted for inclusion in Genocide Studies and Prevention: An International Journal by an authorized editor of Digital Commons @ University of South Florida. For more information, please contact digitalcommons@usf.edu. 


\title{
Genocide and the Hispanic-American Dilemma
}

\author{
Eitan Ginzberg \\ University of Tel Aviv \\ Tel Aviv, Isreal
}

Si mi pluma tuviese don de lágrimas, escribiría una obra titulada El indio, y haría llorar al universo.

(If my pen had the gift of tears, I would write a work called The Indian, and make the universe cry).

Juan Montalvo, $1887^{1}$

In a letter dated September 16, 1501, Queen Isabella I of Castile and King Ferdinand II of Aragón instructed the governor of the Indies (at that time the Caribbean region), Nicolás de Ovando (15021509. Appointed to his post as early as Sep. 3, 1501), to treat the natives in a humane and decent manner, enable them to move about freely, feel secure, and see to it that "no one is allowed to use force against them, rob them, cause them another harm or damage." ${ }^{2}$ The letter also commands Ovando to be gentle and caring, while avoiding all use of coercion when converting the natives to "our holy Catholic faith."

This royal demand of good will and fair treatment toward the Indians contained no statements that could be construed as even hinting at a deliberate intention to harm the native population, certainly as long as they "behaved," that is, accepted the burden of Spanish rule and followed its requirements, which were made clear in the Requirement Document. ${ }^{4}$ Nevertheless, Raphaël Lemkin, like several Latin American historians and genocide scholars after him, was not impressed by this. As far as he was concerned, the "demographic catastrophe" of sixteenth-century Spanish America was a fact, though it was not mainly the result of epidemics, as was widely alleged by most Latin American researchers, but rather deliberate killings, torture and massacres, mass bondage, sexual abuse, deprivation of livelihoods, and extensive exploitation of the indigenous population, carried out in blatant violation of directives, edicts, or official laws, which were hardly ever enforced. ${ }^{5}$ While the local populace seemed to be showered with written professions of empathy and sensitivity, they were made to carry heavy burdens and meet demands they could not possibly cope with. As Lemkin pointed out, an atmosphere of abuse and terror dominated the colony. ${ }^{6} \mathrm{He}$ defined this as genocide, and he was the first to do so.

The present article is an attempt to investigate Lemkin's claim within a framework which I call the colonial paradox, that is, the intertwining of two contradictory policies, conservation and exploitation. The essence of this paradox is that Spain actually intended to protect the Indians from

${ }^{1}$ Antonio Sacoto, El indio en el Ensayo de la América Española (Quito: Universidad Andina Simón Bolívar, 1994), 52.

${ }^{2}$ Translation for the quote is as follow: "ninguno les haga fuerza, ni los roben, ni hagan otro mal ni daño." (originally: "ninguno les faga fuerza, nin los rroben, nin fagan otro mal nin dapño"). Quoted here is 16th century Spanish adapted slightly to modern Spanish. See King Ferdinand II of Aragón and Queen Isabella I of Castile, "Instrucciones al Comendador Frey Nicolas de Ovando. Gobernador de las Islas y Tierra Firme del Mar Oceano" [Instructions to Commander Fray Nicolás de Ovando, Governor of the Islands and Mainland of the Ocean Sea] (Granada, 16 de septiembre de 1501/Granada, September 16, 1501), in Colección de Documentos para la Historia de la Formación Social de Hispanoamérica, 1493-1810. Volume I (1493-1592), ed. Richard Konetzke (Madrid: Consejo Superior de Investigaciones Científicas, 1953), doc. 6, 5.

${ }^{3}$ Ibid.

${ }^{4}$ Refer to page 5 and page 7 of this article.

${ }^{5}$ The provisions of the Spanish Crown to their agents in their American colonies are referred to by various names such as Leyes, Cédulas, Cartas, Provisiones, Instrucciones, Cartas reales, Declaraciones, Ordenanças, Pragmáticas or various combinations such as Leyes y Ordenanças or Carta y Provision real and so on. Despite the different terminology, which express various legal formulations, 16th century jurists regarded them all as laws. See Alfonso Garcia Gallo, "La Ley Como Fuente del Derecho en Indias en el Siglo XVI," Anuario de Historia del Derecho Español 21-22 (1951-1952), 618-620.

${ }^{6}$ Raphaël Lemkin, Spain Colonial Genocide. Raphaël Lemkin Collection, P-154, Box 8, Folder 12 (American Jewish Historical Society, Center for Jewish History: Boston, and New York). 
any harm they might suffer due to its presence in their territories, yet knowingly failed to do so, albeit with a certain amount of anguish. The reason for this failure was, I believe, Spain's knotty national and colonial situation.

America dropped into Spain's lap like manna from heaven. It had no "irresistible necessity" for such a vast continent-at least not from a demographic perspective. ${ }^{7}$ Nevertheless, the discovery of America opened up a military and commercial Pandora's box-an entirely predictable outcome for a society that had been involved in a centuries-long war-and brought Spain face to face with the prospects of wealth, viewed essentially in terms of "gold and booty;" land, i.e., "lordship;" ${ }^{\prime \prime}$ and alien peoples, perceived as "vassals, slaves, and converts." ${ }^{10}$ Since America could easily supply such unexpected assets, as Cortés's letters to King Charles related so convincingly, ${ }_{11}^{11}$ it was only natural to bind them to the Spanish Crown through conquest, a sine qua non of all European countries' "highly developed territorial consciousness" and competitiveness. ${ }^{12}$

Yet, by conquering America and occupying it para su mayor perpetuidad y firmeza ("in perpetuity"), as stipulated in the special royal law of September $1519,{ }^{13}$ Spain actually became trapped in it. At a certain historical moment-let us say, in the middle of sixteenth century-when it was already clear that the natives were being harmed and dying in masses as result of the demanding work and harsh conditions imposed upon them, Spain was no longer in a position to abandon America without severely damaging its status as a significant European power. Leaving America would have meant handing it over to England and France, its main rivals in Europe. It would also have entailed exposing the Indians, many of whom had already converted to Christianity, to further abuse at the hands of greedy settlers, who would definitely remain in America, on the one hand, and enraged pagan groups, who never recognized Spanish rule, on the other. Thus, having no substitute for the native manpower needed to sustain its national and international status, and to uphold its financial obligations to the pioneers and conquerors who had come to America at their own expense, ${ }^{14}$ it appeared that Spain was unable to leave America. ${ }^{15}$ The only option left, after

${ }^{7}$ John H. Elliott, "The Seizure of Overseas Territories by the European Powers," in Theories of Empire, 1450-1800, ed. David Armitage (Aldershot, Hampshire and Brookfield, Vermont: Ashgate, 1998), 139-140.

${ }^{8}$ Ibid., 142.

${ }^{9}$ Ibid.

${ }^{10}$ Ibid.

${ }^{11}$ Anthony Pagden, trans and ed., Hernán Cortés: Letters from Mexico (New Haven and London: Yale University Press, 1986), 40-46; ((first letter, April 1520); 92-96, 99-113 (second letter, April 1522)).

${ }^{12}$ Elliott, The Seizure, 145-157.

${ }^{13}$ King Charles I, “Que las Indias Occidentales estén Siempre Unidas á la Corona de Castilla, y no se pueden enagenar," [That the West Indies are always united to the Crown of Castile, and cannot be alienated], in Council of the Indies (Real y Supremo Consejo de Indias), Recopilación de Leyes de los Reynos de las Indias, ed. Consejo de la Hispanidad. (Madrid: Consejo de la Hispanidad, [1681] 1943), Tomo I, Libro III, Título I, Ley primera (Barcelona, Sept 14, 1519), 523.

${ }^{14}$ This principle, already applied to Columbus during his (first) voyage to the Ocean's Seas (Mares Oçéanas), became a law in September 1573. See, King Philip II, "Que ningun Descubrimiento, ni Poblacion se haga á Costa del Rey" [That no discovery, nor settlement is made at the expense of the King] (Segovia, 13 de julio de 1573/Segovia July 13, 1573), Council of the Indies (Real y Supremo Consejo de Indias), in Recopilación de Leyes de los Reynos de las Indias, ed. Consejo de la Hispanidad. (Madrid: Consejo de la Hispanidad, [1681] 1943), Tomo II, Libro IV, Título I, Ley XVII, 4.

${ }^{15}$ The idea of relinquishing at least some parts of America was actually considered by Philip II in late 1556, a few months after he ascended the throne. Sensitive to the criticism of the Crown's conduct in America, he decided to weight the matter at least with respect to the Viceroyalty of Peru. The Peruvian encomenderos (beneficiaries) represented by Antonio de Rivera, a well-known encomendero (beneficiary) from Quito, offered to purchase their encomiendas (grants) in perpetuity, along with all the associated jurisdiction rights, for 7.6 million ducats, and thus become the exclusive rulers of the Viceroyalty (in reality, all of South America), while maintaining a certain affinity to the Crown. The impoverished Philip was delighted with this proposal and formed a special committee made up of members of the Colonial Council to examine its implications. The committee unequivocally rejected the offer, pointing out that it would allow 300 or 400 encomenderos (beneficiaries) to take over all of South America, enslave the indigenous people and wipe out every last one of them. See, Consejo de las Indias, "Parecer del Consejo de Las Indias de 21 de octubre de 1556 en Repuesta de Ciertos Capítulos que Su Magestad les Enbio a Consultar Desde Gante Tocante a la Perpetuidad de Las Indias," in Juan de la Peña, Luciano Pereña, Escuela Española de la Paz, De Bello Contra Insulanos: Intervención de España en América, II, Escuela Española de la Paz, segunda generación, 1560-1585, Posición de la Corona, ed. Luciano Pereña et al, vol. 10 of Corpus Hispanorum de Pace (Madrid: Consejo Superior de Investigaciones Científicas, 
rejecting the idea of turning Spain into a commercial or protectionist power in America, based upon a contractual relationship with the Indians, ${ }^{16}$ was to continue its harmful, exploitative policy toward the indigenous population.

This situation, which in effect eliminated the Crown's freedom of action in American affairs while creating an inherent contradiction between intentions and the ability to realize them, is what I have called the colonial paradox. This paradox gave birth to a politics of duplicity, which exhibited a firm, but basically hollow, protective approach to the Indians. Although its policies achieved some minor improvements here and there, they were overshadowed by vigorous demands to increase the wealth produced by the colonies, and strict instructions to make no use of the Crown's treasury to fund the colony's maintenance and discoveries (i.e., further conquests). While the Crown appeared to take notice of, and even invite criticism and debate, it also stifled them. Although Church leaders or the King's emissaries would always extol the natives' humanity and natural freedom, in reality, they were treated in a patronizing and superior manner, as if they were minors. They were prohibited from wearing European clothing, riding on horses, possessing weapons, serving in public or religious institutions, training for or holding certain qualified professions, studying in Spanish schools and universities, or residing as individuals beyond the rural Indian "republics" or specified urban neighborhoods. This approach was reinforced with appropriate theological, legal, and moral justifications.

The present article will explore this paradox and point to the contradictions of Spain's colonization of America. These contradictions were exacerbated by Spain's fragile economic situation, as well as theological and ideological pressures, which prevented the implementation of the Crown's humanistic approach. From the standpoint of this perspective, I will attempt to clarify the extent to which the concept of genocide-in the sense that Lemkin used in relation to Spanish America-is the appropriate one to define the human disaster that took place in the lands under Spain's control.

To the best of my knowledge, this is a new and more comprehensive approach for examining the Spanish American impact on the native population. My attempt goes beyond the conventional, linear interpretive method of analyzing action and reaction-which was never able to resolve the historiographic dispute surrounding Spanish American "black" or "white" legends-and suggests a certain inclusive and more encompassing attitude toward the interpretive dilemma of Spanish American colonialism. ${ }^{17}$

\section{Good Intentions}

In March 1503, Queen Isabella I and King Ferdinand II dispatched another communiqué, similar to the previously cited letter of September 1501, instructing Governor Ovando to make sure that

1982), 94-97; Consejo de las Indias, “Recomendaciones del Consejo de Indias Sobre la Perpetuidad en el Peru," in Juan de la Peña, De Bello Contra Insulanos. Intervención de España en América, II, Escuela Española de la Paz, segunda generación, 1560-1585, Posición de la Corona, ed. Luciano Pereña et al., vol. 10 of Corpus Hispanorum de Pace (Madrid: Consejo Superior de Investigaciones Científicas, 1982), 98-101. The Salamancan scholars and las Casas reacted similarly in a lengthy document, De imperatoria seu [sive] regia potestate (The imperial or royal power). If the king accepts the encomenderos' (beneficiaries) offer, they contended, the Indians must be released from all their obligations to the Spanish Crown and be given full rights of self-determination, immune from any possible plans of the Spanish settlers to enslave or exploit them. In the end, after further consideration, the king gave up on the idea. See, Luciano Pereña, "Estudio preliminar," in Bartolomé de las Casas, De regia Postestate o Derecho de Autodeterminación, ed. Luciano Pereña et al., vol. 8 of Corpus Hispanorum de Pace (Madrid: Consejo Superior de Investigaciones Científicas, 1969), xlvi-cxxxviii; Bartolomé Hernández S.J., “Carta de Batolomé Hernández de la Compañía de Jesús y Confesor del Virrey, a Don Juan de Ovando, Presidente del Consejo de Indias" [Letter of Batolomé Hernández], (Lima, 19 de abril de 1572/Lima, April 19, 1572), in José de Acosta, "De procuranda Indorum Salute, o Pacificaión y Colonización," ed. Luciano Pereña et al, vol. 23 of Corpus Hispanorum de Pace (Madrid: Consejo Superior de Investigaciones Científicas, 1984), 642-653; Bartolomé de las Casas, "De Imperatoria seu regia potestate," in Bartolomé de las Casas, De regia Postestate o Derecho de Autodeterminación, ed. Luciano Pereña et al., vol. 8 of Corpus Hispanorum de Pace (Madrid: Consejo Superior de Investigaciones Científicas, 1984), 1-115.

${ }^{16}$ Please refer to the below discussion on page 16-17.

${ }^{17}$ On the history of the "black legend," see Miguel Molina Martínez, "La Lyenda Negra Revisitada: la Polémica Continua," Revista Hispanoamericana 2 (2012), 1-15. 
all Indians have a house where they can live with their families, work the land, and raise cattle. ${ }^{18}$ King Ferdinand II issued a cédula (royal command) in May 1509, which stipulated that the local population should only be asked to take on light tasks, and that they should reside solely in their own communities, and be governed by their own leaders. ${ }^{19}$

The Laws of Burgos (1512), ${ }^{20}$ which provided a legal basis for justifying both the Spanish conquest of America and the exploitation of its indigenous population, endorsed the encomienda (grant) as a benevolent civilizing institution, ${ }^{21}$ while attesting to the natives' status as the legal owners of the land, and asserting that their transfer to the encomiendas (grants) should be done by means of persuasion alone..$^{22}$ The arrangements for their work in the encomienda (grant) fields and mines contained rigid guidelines that gave serious consideration to the appropriate type of employment and nutrition for women, as well as young adults. ${ }^{23}$ The preamble of the Requerimiento (Requirement Document) an important supplementary outcome of the Burgos Conference expressed the following, on the whole quite principled ideas:

And we [the conquerors] in their name [the king of Spain and the Pope] shall receive you in all love and charity, and shall leave you, your wives and your children, and your lands, free without servitude, that you may do with them and with your own selves freely that which you like and think best, and they shall not compel you to become Christians, unless you yourselves, when informed of the truth, should wish to be converted to our Holy Catholic Faith..$^{24}$

In December 1526, an unequivocal royal decree demanded that native populations no longer be sent to the gold mines in the Caribbean islands, since so many of them fell victim to the harsh

${ }^{18}$ King Ferdinand II of Aragón and Queen Isabella I of Castille, “Introducción al Comendador Nicolás de Ovando, Gobernador de la Islas y Tierra Firme, Sobre el Modo y Manera de Concentrar a la Población Indígena Dispersa en Pueblos" [Introduction to Commander Nicolás de Ovando, Governor of the Islands and Mainland, on the manner of concentrating the dispersed indigenous population in towns] (Alcalá de Henares, 20 de marzo y Zaragoza, 29 de marzo, 1503/Alcalá de Henares, March 20, 1503 and Zaragoza, March 29, 1503), in Cedulario de Tierras: Compilación de Legislación Agraria Colonial (1497-1820), ed. Francisco de Solano (México D. F.: Universidad Nacional Autónoma de México, 1984), doc. 4, 110.

${ }^{19}$ Ronald D. Hussey, “Text of the Laws of Burgos (1512-1513) Concerning the Treatment of the Indians," Hispanic American Historical Review 12, no. 3 (1932), 302.

${ }^{20}$ The Laws of Burgos were an outcome of the Burgos Conference, a gathering of jurists, theologians, and representatives of the Dominican Order, convened in the summer of 1512 (presumably in August) in Burgos, at the request of King Ferdinand II and the Royal Council, in response the Dominican delegation's outcry against the brutal exploitation of the Indians which they had witnessed in Española in 1510-1511. The conference discussed a number of issues concerning the status of the Spanish Crown in America, the civil status of the natives, their proper treatment, and the process of their Christianization. The final document issued by the conference consisted of seven introductory statements plus thirty-five laws. The Ordenanzas Para el Buen Tratamiento de los Indios (ordinances regarding the good treatment of the Indians) were approved on December 27, 1512.

${ }^{21}$ The encomienda (grant) was an allocation of land and a group of indigenous inhabitants to a Spanish settler for his use and benefit. Typically, they were assigned to officers and soldiers who took part in expeditions of conquest and pacification. Encomienda (grant) holders were not considered to be the owners of the lands assigned to them, rather they held temporary rights of possession, which remained officially valid for three to four generations, but unofficially as long as the family in question wished to retain it. Encomienda (grant) recipients were also required to Christianize the indigenous inhabitants and provide for their spiritual well-being. Since early seventeenth century, the hacienda (estate) gradually replaced the encomienda (grant).

${ }^{22}$ Jorge Augusto Gamboa M., "La Encomienda y las Sociedades Indígenas del Nuevo Reino de Granada: el Caso de la Provincia de Pampelona (1549-1650)," Revista de Indias 64, no. 232 (2004), 752.

${ }^{23}$ Hussey, Text of the Laws of Burgos, 306-323; Bartolomé de las Casas, Historia de las Indias, vol. 3 (Caracas: Imprenta Ayacucho, 1986), 53-71; King Philip II, “Real Cédula. A la Audiencia de Guatemala, Ordenando se haga Justicia en Ciertas Usurpaciones de Tierras Baldíos y Edjidos en Términos de Santiago de Guatemala" [Royal Decree. To the Audience of Guatemala, ordering justice to be done in certain usurpations of vacant [tierras baldios] and public community lands [ejidos] in the realm of Guatemala] (El Escorial, 10 de marzo, 1566/ El Escorial, March 10, 1566), in Cedulario de Tierras: Compilación de Legislación Agraria Colonial (1497-1820), doc 79, ed. Francisco de Solano (México D. F.: Universidad Nacional Autónoma de México, 1984), 204-205.

${ }^{24}$ Lewis Hanke, “The 'Requerimiento' and Its Interpreters," Revista de Historia de América 1, no. 1 (1938), $26-28$. 
working conditions. "Almost no natives remain on these islands today," declared the king. ${ }^{25}$ This was a logical continuation of a decree issued one month before, which outlawed slavery in Spanish America, and ordered the full and complete liberation of all enslaved Indians, including those who vehemently rejected Spain's domination and rebelled against it. ${ }^{26}$ On June 9, 1537, Pope Paul III issued a papal bull, Sublimis Deus (the sublime God), which affirmed the native population's status as full-fledged, free individuals. ${ }^{27}$ In order to remove any doubt regarding his steadfast stance on the rights of the indigenous peoples, the Pope issued another papal bull entitled Veritas ipsa (the truth itself) in same month, which sharply criticized their enslavement and openly supported the king's aggressive campaign against it. ${ }^{28}$

In January 1539, Francisco de Vitoria, head of the cathedra of theology at the University of Salamanca and an influential advisor to King Charles delivered a lecture entitled De indis recenter inventis (On the Indians lately discovered), in which he resolutely refuted all the condemnations against the Indians, who were generally believed to be amentes vel insensati (insane or foolhardy). He declared that they were totally rational and normal people, and could, therefore, be full-fledged owners of their properties (i.e., absolutely sovereign), which they were fully capable of managing. ${ }^{29}$ According to Charles's New Laws of 1542, all the encomiendas (grants), which the monarch had accused of harming the Indians, were to be dismantled and their lands and properties returned to the state, immediately upon the death of their original owner. ${ }^{30}$ The Ovandino Codex of King Philip II, a partial collection of laws relating to the colony and adopted before 1573, focused on different aspects of the religious, administrative, and judicial life in America. ${ }^{31}$ The Requirement Document was abrogated; the word "conquest" in official papers was changed to "discovery;" and the indigenous population's absolute freedom of movement, self-government, and freedom from bondage was declared and reconfirmed. ${ }^{32}$

From 1503, a major relocation (officially described as reducción or congregación) of the local population was considered. The idea was to create autonomous Indian communities, officially known as repúblicas de indios (Indian republics), where it would be easier to control, convert, and organize them economically, while protecting them from Spanish abuse. The entire shift to new communities, which was intensively implemented over the following 150 years, was based upon persuasion and good will, generous allocations of land, with protection from any type of subjugation or land expropriation, as well as development grants, preferential treatment for caciques (leaders),

${ }^{25}$ King Charles I, "Real Cédula. Para que los Indios no se echen en las Minas" [Royal Decree: That the Indians are not compelled to work in mines] (Granada, 8 de diciembre de 1525/Granada, December 8, 1525), in Colección de Documentos para la Historia de la Formación Social de Hispanoamérica, I, ed. Richard Konetzke (Madrid: Consejo Superior de Investigaciones Científicas, 1953-1958), doc. 48, 97-98.

${ }^{26}$ King Charles I, "Que los Indios sean Libres, y no Sujetos á Servidumbre" [That the Indians be free, and not subject to servitude] (Granada, 9 de noviembre de 1526/Granada, November 9, 1526), in Recopilación de Leyes de los Reynos de las Indias, ed. Council of the Indies (Real y Supremo Consejo de Indias), (Madrid: Consejo de la Hispanidad, 1943 [1681]), Tomo II, Libro VI, Título II, Ley I, 201. This law was restated in 1530, 1532, 1540, 1542, and 1548.

${ }^{27}$ Lewis Hanke, "Pope Paul III and the American Indians," The Harvard Theological Review 30, no. 2 (1937), 73-74, 83-85; Jesús María Añoveros, “Carlos V y la Abolición de la esclavitud de los Indios," Revista de Indias 60, no. 218 (2000), 8081.

${ }^{28}$ Hanke, Pope Paul III, 74; Añoveros, Carlos V y la Abolición, 81-83.

${ }^{29}$ Francisco de Victoria, De Indis et de Iure Belli Relectiones, ed. Ernest Nys (Buffalo, NY: William S. Heim and Co., 1995), 120-128 [fols. 315-336].

${ }^{30}$ Añoveros, Carlos V y la Abolición, 70-81.

${ }^{31}$ King Phillip II and the Colonial Council initiated the classification of the vast number of laws, orders, guidelines, and directives (or, in more general terms, "royal dispositions") pertaining to the colony into neat files, a task that was only completed in 1681.

${ }^{32}$ El Ministerio de la Vivienda/Spanish Ministry of Housing, Transcripción de las Ordenanzas de Descubrimiento, Nnueva Población y Pacificación de las Indias dadas por Felipe II, el 13 de julio de 1573, en el Bosque de Segovia, según el original que se conserva en el Archivo General de Indias de Sevilla [Transcription of the Ordinances of discovery, erecting new (Indian) towns and pacification of the Indies given, by King Philip II on July 13, 1573 in the Forest of Segovia, according to the original that is preserved in the General Archive of the Indies of Seville] (Madrid: El Ministerio de la Vivienda, 1973), articles 29, 30; Silvio Zavala, New Viewpoints on the Spanish Colonization of America (New York: Russel and Russel, 1968), 42; Angel Martín González, Gobernación Espiritual de Indias: Código Ovandino, Book I (Guatemala: Instituto Teológico Salesiano, 1977), 18. 
long-term exemptions from taxes and levies, and organized agreements for the registration of private land ownership. ${ }^{33}$

\section{The Reality}

It turned out, however, that the reality was much more complex than what these examples portray. First, it is important to note that by 1681 a vast number of orders and directives-more than 400,000 as well as 6,447 laws had been drawn up with the aim of organizing life in the colony, ${ }^{34}$ thousands of them in reaction to injurious behavior toward the native population perpetrated by the Crown's agents. ${ }^{35}$ Yet, these directives, which contained instructions about the proper treatment of the natives, often contained internal contradictions. The same document might put forth certain demands or assertions, and in the next breath, conflicting demands, making it impossible to implement a strategy of defending the Indians, while exacerbating an already difficult status quo.

Furthermore, almost all the laws or directives that addressed crucial issues such as slavery, personal services (provided to encomenderos (beneficiaries) in lieu of tribute (poll tax) levies, but tantamount to slavery), hazardous work, the disruption of daily life, etc., contained "loopholes for abuse," ${ }^{\prime 36}$ as the famous Spanish oidor (judge), Alonso de Zorita, called them in late 16th century, or "permitted loopholes," as Matthew Restall has call them today. ${ }^{37}$ Such loopholes undermined the implementation of these laws, creating a distorted legal status, which the Swedish hispanista (specialist in Spanish history and culture), Magnus Mörner, termed "non-compliance of the law as a legal institution." ${ }^{38}$ Indeed, as early as 1647, the famous jurist Juan de Solórzano y Pereyra noted that this situation allowed considerable room for the "adaptation" of royal decrees and laws "segun lo piden los casos" ("with respect to the demands of the moment"). Such adaptations related not to the urgent needs of the Indians, but to those of the Spanish kings, settlers, and others. ${ }^{39}$ The following examples illustrate this paradox in a number of areas.

The abovementioned letters dispatched to Governor Nicolás de Ovando were not sent without cause. Just as Queen Isabella 1 and King Ferdinand II demanded he treat the indigenous population with respect and consideration, so, too, was he required to supply native workers for the mines, fields, and construction sites in the cities. Recruiting these workers made it possible for Ovando to supply the king and queen with the means to maintain the colony, i.e., by allocating a respectable quinta (fifth) of its revenues to the royal treasury. In order to achieve this goal, they allowed Ovando to uproot the Indian population from the islas inútiles ("useless islands"), where no gold was found, with most of them being sent first to Española ${ }^{40}$ (or the isla de oro (isle of gold)), and after 1511, to Cuba as well, following its conquest. Yet, because some groups of Indians refused to work, or to work for Spain, and at times vehemently resisted or fled this forced transfer, the "relocation" crusade turned into a ruthless manhunt in which the captured natives were defined as Prisoners of War (POWs)-since this was seen as a "just war"-and enslaved. Utter chaos ensued along with a rapid decrease in the indigenous population, which Ovando could not control. ${ }^{41}$ Ferdinand's way of dealing with the situation was to send the abovementioned royal warrant to Don Diego

\footnotetext{
${ }^{33}$ King Charles I, “Real Provisión. Por la que se ordena la Creación de Pueblos con la Población Indígena Dispersa y con la que se encuentra Encomendada, Dotándoles de Tierras y Bienes" [Royal Provision. By which it is ordered the creation of (Indian) towns, based upon dispersed indigenous population and in which it (the Indians) would be entrusted, providing them with lands and (agricultural) resources] (Cigales, 21 de marzo, 1550/Cigales, March 21, 1550), in Cedulario de Tierras: Compilación de Legislación Agraria Colonial (1497-1820), ed. Francisco de Solano. (México D. F.: Universidad Nacional Autónoma de México, 1984), doc. 57, 181-183; Kings Charles I, Philip II, Philip III and Philip IV, “De las Reducciones y Pueblos de Indios [1551-1648]" [On the reductions and towns of Indians], in Recopilación de leyes de los Reynos de las Indias, ed. Consejo de la Hispanidad (Madrid: Consejo de la Hispanidad, [1681] 1943), Tomo II, Libro VI, Título III, Leyes I-XXIII, 207-212.

${ }^{40}$ Española (or Hispañola) is the island located east of Cuba. Its capital, Santo Domingo, was the center of Spanish rule in circum Caribbean until the establishment of the two colonial centers of control in Mexico and Peru after their discovery and conquest (1519-1533 respectively).

${ }^{41}$ Ángel Rosenblat, La Población Indígena y el Mestizaje en América: Tomo I: La Población Indígena, 1492-1950 (Buenos Aires: Editorial Nova, 1954), 111; Andrés Reséndez, The Other Slavery: The Uncovered Story of Indian Enslavement in America (Boston and New York: Houghton Mifflin Harcourt, 2016), 37-45.
} 
Colón, Governor of the Indies (1509-1518), in May 1509.42 Yet, in November, as if ignoring his earlier, benevolent cédula (royal command), he demanded that his treasurer in Española, Miguel de Pasamonte, do everything in his power to increase productivity. ${ }^{43}$ The withholding of half of the Castilian income following the death of Queen Isabella I in $1504,{ }^{44}$ while his responsibilities as the ruling monarch of Spain remained the same, left him no choice.

The Crown initiated the abovementioned Burgos Conference in response to the storm that swept Española in the wake of two sermons delivered by Antonio de Montesinos, the Dominican representative, in November and December 1511, and the harsh criticism of the treatment endured by the indigenous population which they contained..$^{45}$ The Burgos Laws, the outcome of the conference convened in the Castilian capital, demanded more humane treatment of the native population-men, women, and children-but they lacked authority and failed to impress the colonists, who were struggling with a dwindling native workforce and a demanding quinta (fifth). Furthermore, the second part of the Requerimiento (Requirement Document) drawn up at the conference empowered the officials in America to wage war against the Indians who refused to acquiesce to their demands:

[We] shall forcibly enter your country and make war against you in all ways and manners that we can, and subject you to the yoke and obedience of the Church and of their Highness[es], we shall take you and your wives and your children, and shall make slaves of them, and as such shall sell and dispose [of] them as their Highnesses may command; and we shall take away your goods, and shall do all the harm and damage that we can. ${ }^{46}$

Charles I, who ascended the throne in March 1516, was no less concerned than his predecessor (and grandfather) about the decline of the Crown's income due to the rapid waning of the native Caribbean population, which continued to decline due to the smallpox epidemic that spread through the region in 1518. Unable to find a creative alternative for the desperately needed manpower of his Circum-Caribbean colony, which was intended to produce a sizeable surplus for his imperial treasury, Charles extended Ferdinand's manhunt policy in the Lesser Antilles to the 1,000 km coastline of the Tierra Firme del Mar Océano, the northern region of present day Venezuela, an area his grandfather, apparently under the influence of the Burgos Conference, had tried to preserve for the missionary activity of the Dominicans and Franciscans from Santo Domingo. ${ }^{47}$ In order to justify his decision to make the Caribes (the name given to the region's Indian population in 1493) fair game for capture and enslavement, Charles, relying on evidence provided by none other than the slave hunters, branded the Caribes as rebellious cannibals. ${ }^{48}$

As time went on and the demographic catastrophe in the Caribbean became evident, the king was forced to ban any type of indigenous labor in that area, outlaw slavery there and in all of Spanish America, and cancel any previously granted slave hunting permit. Obviously, King Charles's response of 1526 came too late. Worse still, it didn't spare the Caribes (and by extension any belligerent Indians). Charles's acceptance of their negative image made the slave hunters feel that

${ }^{42}$ King Ferdinand II, “Real Instrucción. A Don Diego Colón, Almirante y Gobernador de las Indias” [Real Instruction. To Don Diego Colón, Admiral and Governor of the Indies] (Valladolid, 3 de mayo de 1509/Valladolid, May 3, 1509), in Colección de Documentos para la Historia de la Formación Social de Hispanoamérica, I, ed. Richard Konetzke (Madrid: Consejo Superior de Investigaciones Científicas, 1953-1958), doc 13, 19-20; Diego Colón was appointed governor in August 1518 and arrived at Santo Domingo in the August of the following year.

${ }^{43}$ Hussey, Text of the Laws of Burgos, 302.

${ }^{44}$ Richard Konetzke, América Latina, Tomo II: La época colonial (México: Siglo XXI, [1965] 1991), 100.

${ }^{45}$ Las Casas, Historia de las Indias, vol. 3, 12-24; Antonio García y García, "El Sentido de las Primeras Denuncias," in Francisco de Vitoria y la Escuela de Salamanca: La Ética en la Conquista de América, ed. Demetrio Ramos Pérez et al., vol 25 of Corpus Hispanorum de Pace (Madrid: Consejo Superior de Investigaciones Científicas, 1984), 67-72.

${ }^{46}$ Lewis Hanke, The Spanish Struggle for Justice in the Conquest of America (Dallas: Southern Methodist University Press, [1949] 2002), 33.

${ }^{47}$ Erin Stone, “Slave Raiders Vs. Friars: Tierra Firme, 1513-1522," The Americas 74, no. 2 (April 2017), 149-155, 161-163; Reséndez, The Other Slavery, 134.

${ }^{48}$ Stone, Slave Raiders Vs. Friars, 162 and note 87; Esteban Mira Caballos, El Indio Antillano: Repartimiento, Encomienda y Esclavitud (1492-1542) (Sevilla and Bogotá: Muñoz Moya Editores, 1997), 291-294. 
they could ignore the king's orders, certainly with respect to the Caribes. ${ }^{49}$ This situation apparently empowered King Philip's decision in January 1569 to exclude the Caribes from the sweeping, overall ban on bondage in America. It is puzzling, however, that knowingly or unknowingly, King Philip extended this exemption for all time. Indeed, it was integrated into the compilation of Recopilación de leyes de los Reynos de las Indias (Spanish colonial laws) of 1681, as though time had frozen somewhere in November 1526 or January $1569 . .^{50}$ This loophole decision unleashed an enterprise that hunted down and enslaved 235,000 to 410,000 human beings in Circum Caribbean alone, up to year 1800, most of them Caribes, and an additional 1,770,000-3,600,000 Indians in other Spanish-American enclaves ${ }^{51}$ According to the mortality rate in the Circum Caribbean during the early sixteenth century, it is apparently safe to assume that few of these people survived. Needless to say, King Charles's actions in 1520 against the Caribes critically damaged the work of the missionaries operating in northern Colombia and Venezuela. But, as we have, and will continue to see, when the Crown's revenues conflicted with the Church's interests, the latter were ignored. ${ }^{52}$

Another example is Pope Paul III's abovementioned bull, which was written in response to the distress of the Church leaders in Mexico, who were appalled by the impact of Domingo de Betanzos's condemnation against the Indians, i.e., that they lacked interest in Christianity and were too primitive to grasp the complexity of the Christian faith. ${ }^{53}$ Yet precisely one year after sending his seal, the Pope was forced to annul the penalty clause, including the section pertaining to the punishment that would befall anyone who dared inflict harm on the indigenous population. ${ }^{54}$ The king regarded the papal document as a violation of his authority, and demanded the termination of the Holy See's display of independence..$^{55}$ As Lewis Hanke asserted, "Paul III took away with one hand what he gave with the other." 56

In a similar vein, it is important to note the sharp about-face taken by Francisco de Vitoria in his lecture De Indis (On the Indians) of January 1539. Even though the first part of his lecture praised the local populations for their political, judiciary, and cultural initiative during the period preceding the arrival of the Spanish, the third and last part argues that it would be impossible to place control in the hands of the Indians following the Spanish conquest because they are still "people of defective intelligence; and indeed they are no whit or little better than such, as far as self-government is concerned, or than wild beasts, for their food is not more pleasant and hardly any better than that of beasts. ${ }^{\prime 57}$ Vitoria understood this as being indicative of a flawed body and soul, which meant that "some are by nature slaves, for all the barbarians in question are of that type and so they may in part be governed as slaves are." ${ }^{\prime 5}$

The new, decidedly protective laws drawn up in November $1542,{ }^{59}$ would never have been promulgated had it not been for the harsh criticism of Bartolomé de las Casas, who described the

${ }^{49}$ Restall, When Montezuma Met Cortés, 300; Mira Caballos, El Indio Antillano, $294-302$.

${ }^{50}$ Consejo de la Hispanidad, "Que los Caribes, que fueren á hacer Guerra á las Islas, se hagan Esclavos, como se ordena" [That the Caribs, who will make war (against the Spanish invaders) on the (Circum-Caribbean) Islands, will be enlasved as ordered], in Recopilación de Leyes de los Reynos de las Indias, edited by Consejo de la Hispanidad (Madrid: Consejo de la Hispanidad, [1681] 1943), Tomo II, Libro VI, Título II, Ley XVIII, 204-205.

${ }^{51}$ Reséndez, The Other Slavery, Appendix I, 324.

52 Stone, Slave Raiders Vs. Friars, 150-155, 160-170.

${ }^{53}$ Patricia Seed, “'Are These Not Also Men?' The Indians' Humanity and Capacity for Spanish Civilisation," Journal of Spanish American Studies 25, no. 3 (1993), 643; David E. Stannard, American Holocaust: Columbus and the Conquest of the New World (New York and Oxford: Oxford University Press, 1992), 218; Hanke, Pope Paul III, 82-84; Lewis Hanke, Aristotle and the American Indians: A Study in Race Prejudice in the Modern World (Bloomington: Indiana University Press, 1970), 23-24.

${ }^{54}$ Hanke, Pope Paul III, 86-90 Ferdinand II resorted to a similar stratagem in 1505. See, Hanke, Pope Paul III, 76.

${ }^{55}$ J. Lloyd Mecham, "The Church in Colonial Spanish America," in Colonial Hispanic America, ed. A. Curtis Wilgus (New York: Russell \& Russell, 1963), 200-214.

${ }^{56}$ Hanke, Pope Paul III, 91.

${ }^{57}$ de Victoria, De Indis, 160-161 [fols. 406-407].

58 de Victoria, De Indis, 161 [fol. 408].

${ }^{59}$ King Charles I, “Nuevas Leyes y Ordenanzas para la Gobernación de las Indias y Buen Tratamiento y Consevación de los Indios," in Juan de la Peña, De bello Contra Insulanos. Intervencíon de España en América II, Escuela Española de la 
catastrophic situation in America to the king, after his return to Spain at the beginning of $1540 .{ }^{60}$ Las Casas prepared two position papers, which he submitted to the Royal Councils-now known as the Council of Castile and the Council of the Indies-one regarding the reasons for the numerical decline of the indigenous populations, and the other entitled "Twenty Arguments against the Encomiendas (beneficiaries)." Both papers called for the disbanding of the encomienda (grant) system, which las Casas held responsible for most of the problems, and its replacement with a plan of colonization that was humanistic in nature. ${ }^{61}$ To Las Casas's mortification, the laws were never implemented. An open rebellion of the colonists instigated and led by Gonzalo Pizarro, Francisco Pizarro's halfbrother, in Peru, was nipped in the bud, and ended with the murder of Viceroy Blasco Núñez Vela, who had insisted on implementing the new laws. In New Spain, Viceroy Antonio de Mendoza prevented their publication, fearing that a similar rebellion would break out there, too. The fierce reactions to the new laws forced the king to moderate them, so that their main purpose, the annulment of the encomienda (grant) system, was avoided. ${ }^{62}$

In the famous debate held in Valladolid, the king, ever wavering on colonial issues, summoned las Casas, protector of the Indians, and Juan Ginés de Sepúlveda, a historian and priest known for his Aristotelian and rigid approach to the indigenous peoples, to address the matter of their status and treatment. No decision was reached, however. In fact, the king did not allow the fourteen venerable judges, who had heard the various testimonies during the two rounds of hearings-the first in August-September 1550 and the second in April-May 1551-to hand down their rulings. ${ }^{63}$

The 1575 laws promulgated by Philip II also stemmed from the continuing demographic decline in the colonies. In 1568, the king received a memorandum entitled Memorial sobre la despoblación y destrucción de Indias (Memorial on the depopulation and destruction of the Indies). Written by Father Louis Sánchez and sent to the king by his chief inquisitor, Bishop Diego Espinoza, it contained disturbing news about the oppressive treatment of the native population by the Spaniards. Father Sánchez claimed that they were behaving like "greedy people who always wanted more, whose only goal was to become rich at the expense of Indian sweat and blood." 64 Angered by this report, the king blamed the situation on the Council of the Indies and demanded an immediate investigation into the situation in the colonies. In addition, he ordered the convening of a Junta Magna (special assembly) of the Council in 1568, which was charged with providing a precise definition of the rights of the Indians. The investigation, conducted by the prominent priest and jurist, Juan Ovando y Godoy-who was also a member of the Royal Council at that time-lasted more than a year and did, in fact, prove that the Council was virtually blind to the grim realities in the colony.$^{65}$ The result of this process, the Codex Ovandino, ensured the Indians' freedom, but it did not abolish the mandatory Christianizing, poll tax, and forced labor, which continued to grow, by order of King Philip himself. ${ }^{66}$ The king also authorized the use of force against Indians who objected to Christianization or to the building of Spanish colonies in the areas where they resided. ${ }^{67}$

Paz, segunda generación, 1560-1585, Posición de la Corona, ed. Luciano Pereña et al, vol. 10 of Corpus Hispanorum de Pace (Madrid: Consejo Superior de Investigaciones Científicas, 1982), 102-119.

${ }^{60}$ Bartolomé de las Casas, A Short Account of the Destruction of the Indies (London: Penguin Books, 1992), 128. Las Casas left for Spain at the end of 1539 as a delegate of the bishop of Guatemala, Francisco Marroquín. The aim was to present his findings to the Colonial Council and find ways to repair the tremendous damage that had been done in Honduras, Guatemala, Tierra Firme, and Peru. See, Antonio de Remesal, Historia General de las Indias Occidentales y Particular de la Gobernación de Chiapa y Guatemala I, no. 4 (Madrid: Atlas, 1964), 291.

${ }^{61}$ On December 8, 1542, de las Casas finished writing a book entitled A Short Account of the Destruction of the Indies. The main principles of his position were clarified in this manuscript, which he submitted to the king. See, de las Casas, $A$ Short Account, 127.

${ }^{62}$ Juan Bautista Vilar, “El Murciano Juan López, Procurador General de Tunja y Líder de la Revuelta Neogranadina Contra las Leyes Nuevos," Revista de Indias 54, no. 202 (1994), 563-571.

${ }^{63}$ Hanke, Aristotle, 74-75.

${ }^{64}$ González, Gobernación Espiritual de Indias, 16.

${ }^{65}$ Ibid., xlii

${ }^{66}$ Ibid., 18; Carlos Sempat Assadourian, “La Despoblación Indígena en Perù y Nueva España durante el siglo XVI y la Formación de la Economía Colonial” (relativo a México y a Perú), Historia Mexicana 38 (1989), 426-427 and note 3, 427.

${ }^{67}$ El Ministerio de la Vivienda, Transcripción de las Ordenanzas, articles 3, 11, 20, 86-87, 146. See also, El Ministerio de la Vivienda, Transcripción de las Ordenanzas, 10-22, 64-65, 110-111. 
The Third Provisional Convention of the Mexican Church (including Guatemala, Honduras, and the Philippines), which took place in Mexico in 1585, exposed the very harsh reality of the indigenous communities. ${ }^{68}$ Although originally convened to deal with apostolic matters, the convention-following the demands of the religious orders' representatives, and some of the lawyers and theologians who had been summoned as advisors-addressed two burning issues affecting daily life in New Spain: repartimiento (forced labor) and the cruel war against the indigenous population of north and north-west Mexico, referred to by the generic Nahuatl name chichimecas (Chichimecans). ${ }^{69}$ The Franciscan delegation to the convention faithfully described the critical overall situation, which included the mass deaths of forced mine laborers, the assigning of forced laborers to forbidden work (forestry, portage, and construction), the many over- or underage laborers, the overworking of laborers, serious abuse by unchallengeable Spanish settlers and caste members of defenseless Indian women left at home while their husbands were on labor assignments, underfeeding and starvation in workplaces, physical and emotional abuse, slave wages, and, finally, the near-total depletion of the Indian population due to mass deaths and desertions. The Franciscans compared the Indians to sheep, who had died because their shepherds had entrusted them to wolves, ${ }^{70}$ and concluded that continued compulsory work would bring about the total demise of the colony, and the everlasting disgrace of Spain's future generations. ${ }^{71}$

A similar view was presented in relation to the Chichimecan War. Delegates of the four religious orders maintained that the Spanish themselves expected to benefit financially by capturing the Chichimecans and either putting them to work in the mines of Zacatecas, or selling them into slavery (in slave markets located as far away as Guatemala). ${ }^{72}$ Their actions had frightened the local population into responding violently to Spanish infiltration into their natural habitat. The Spaniards, in turn, reacted by declaring all-out war (justified, in their eyes) against the Indians, resulting in the ultimate death of a staggering number of them. ${ }^{73}$

The reality of the Indian relocation (or rather, displacement) process also reveals the disparity between declared intent and reality, and the inherent discrepancies of the edicts. On the one hand, persuasiveness and goodwill were endorsed, while on the other, the use of force was permitted if the Indians refused to relocate. Furthermore, it was decided that following relocation, the abandoned settlements would be burnt so the Indians could not return to them or use them as

${ }^{68}$ Formal decisions made by the convention were only confirmed for publication in 1622. See Stafford Poole, "The Church and the Repartimientos in the Light of the Third Mexican Council, 1585," The Americas XX (1963), 6-7, note 10; C. M. Stafford Poole, Pedro Moya de Contreras: Catholic Reform and Royal Power in New Spain, 1571-1591 (Berkeley: University of California Press, 1987), 201. No other documents-including the opinions submitted to the convention governancewere destined for publication. Their first complete publication appeared in 2006. See Stafford Poole, "Historia de los Manuscritos Conciliares," in Manuscritos del Concilio Tercero Provincial Mexicano (1585), ed. Alberto Carrillo Cázares (Zamora y México: El Colegio de Michoacán y La Universidad Pontíficia de México, 2006), vol. I, cv.

${ }^{69}$ The Chichimecan War was actually a series of campaigns of revenge, ethnic cleansing, and slave hunts waged against the Chichimecans, the semi-nomadic groups living north of the Lerma River in New Spain (Nueva España), who refused to surrender to the Spanish invasion of their territories. Conducted in waves from 1529 to 1585 , this was a particularly brutal war, named by the Spaniards themselves as "Guerra a fuego y a sangre" (a war of fire and blood). In the 1590s, a change in government policy introduced a conciliatory trend, which lasted for about thirty years. Yet, the needs of the growing mining industry supported the continued encroachment of slave hunters for the next century. These raids, along with the waves of epidemics that attacked this vast area in 1564, 1576, and 1593, brought about the destruction of much of the population. See, Philip Wayne Powell, Soldiers, Indians and Silver: The Northward Advance of New Spain, 1550-1600 (Berkeley: University of California Press, 1952), chapters 4-12; Alberto Carrilo Cázares, ed., El Debate Sobre la Guerra Chichimeca, 1531-1585: Derecho y Política en la Nueva España, 2 vols. (Zamora: El Colegio de Michoacán, 2000); Salvador Álverez, "La Guerra Chichimeca," in Historia del Reino de la Nueva Galicia, eds. Thomas Calvo and Aristarco Regalado (Guadalajara: Universidad de Guadalajara, Centro Universitario de Ciencias Sociales y Humanidades, 2016), 221-239; Reséndez, The Other Slavery, 81-123.

${ }^{70}$ Alberto Carrilo Cázares, ed., Manuscritos del Concilio Tercero Provincial Mexicano (1585), 4 vols (Zamora y México: El Colegio de Michoacán y La Universidad Pontíficia de México, 2006), vol. II, no.1, fol. 127, 343; Poole, The Church and the Repartimientos, 15.

${ }^{71}$ Cázares, ed., Manuscritos del Concilio Tercero, vol. II, no. 1, fols. 127-128, 345.

${ }^{72}$ Silvio Zavala, “Nuño de Guzmán y la Esclavitud de los Indios," Historia Mexicana 1, no. 3 (1952), 411-428; Salvador Álverez, “Conquista y Encomienda en la Nueva Galicia durante la Primera Mitad del Siglo XVI: ‘Bárbaros' y 'Civilizados' en las Fronteras Americanas," Relaciones 29, no. 116 (2008), 153-156.

${ }^{73}$ Cázares, ed., Manuscritos del Concilio Tercero Provincial Mexicano, vol. II, no. 1, fol. 89, 262-263. 
shrines. ${ }^{74}$ Additionally, it was a common practice to relocate Indians far away from their traditional lands, where there were no plots for their personal use, as required by the transfer laws. ${ }^{75}$ Later on, in stark contrast to the strict protective separation of the Indian republics from any nearby Spanish settlement, there were endless reports of livestock entering fields belonging to Indians and consuming their $\mathrm{crops}^{76}{ }^{7}$ illegal trespassing by Spanish and caste members through native territory, the molestation and even the kidnapping of native women and children, ${ }^{77}$ coercion and enticement to sell privately owned or even community owned possessions (the sale of which was prohibited) to the Spanish for the price of a shirt and a bottle of wine, ruthless demands for unpaid work for the confradías (religious brotherhood), and hospitals run by the priesthood inside the Indian republics.

Overall, the Indians were exposed to a form of oppression that brought about premature death, despair, and the forsaking of farming, to the point where entire settlements were deserted, a situation which Meléndez Váldes's 1791 report called Sensible Decadencia (Notable Decline). ${ }^{78}$ Decadencia (decline) was the result of systematically applied methods of pressure, abuse, and harassment imposed on the indigenous population for generations. ${ }^{79}$ At the same time, a ceaseless stream of royal cédulas (royal commands) and laws emphatically demanded an end to these horrendously lethal practices. For the most part, however, official instructions and laws were ignored or adjusted, as Solórzano and Mörner pointed out..$^{80}$

${ }^{74}$ Francisco de Solano, ed., Cedulario de Tierras, Compilación de Legislación Agraria Colonial (1497-1820) (México D.F.: Universidad Nacional Autónoma de México, 1984). 83.

${ }^{75}$ King Philip II, “Que á los Indios Reducidos no se quiten las Tierras que ántes hubieren Tenido" [That the lands previously owed by the Indians will not be taken from them while being resettled], [Toledo, 19 de Febrero de 1560/ Toledo, February 19, 1560]), in Recopilación de Leyes de los Reynos de las Indias, Tomo II, LibroVI, Título III, Ley IX, ed. Consejo de la Hispanidad (Madrid: Consejo de la Hispanidad, [1681] 1943), 209.

${ }^{76}$ King Philip II, “Real Cédula. Por la que se ordena que entre Haciendas y Pueblos de Indios Exista por lo Menos una Distancia de Media Legua" [Royal Decree. By which it is ordered that between (Spanish) haciendas and Indian towns there should be a distance of at least half a league] (Tomar, 1 de mayo de 1581/Tomar, May 1, 1581), in Cedulario de tierras Compilación de Legislación Agraria Colonial (1497-1820), ed. Francisco de Solano (México D. F.: Universidad Nacional Autónoma de México, 1984), doc. 117, 258; King Philip II, “Real Cédula. Al virrey y audiencia de México ampliando a 600 varas a la redonda los términos del pueblo de indios y a 1,100 varas los límites de fujación de las estancias..." [Royal Decree. To the Viceroy and Audience of Mexico, extending to 500 meters around the limits of the Indian towns and to 920 meters around the limits of the cattle ranches ... ] (Madrid, Junio 4 de 1687/Madrid, June 4, 1687), in Cedulario de tierras Compilación de Legislación Agraria Colonial (1497-1820), ed. Francisco de Solano (México D. F.: Universidad Nacional Autónoma de México, 1984), doc. 181, 365-366.

${ }^{77}$ King Charles I, "Real Cédula. Para que las Estancias de Ganados se sitúen Lejos de los Pueblos y Sementeras de los Indios" [Royal Decree. That the cattle ranches are located away from the Indian towns and their cultivated plots] (Valladolid, 24 de marzo, 1550/Valladolid, March 24, 1550), in Cedulario de Tierras Compilación de Legislación Agraria Colonial (1497-1820), ed. Francisco de Solano (México D. F.: Universidad Nacional Autónoma de México, 1984), doc. 51, 173; King Philip II, "Real Cédula. Por la que se ordena que Entre Haciendas y Pueblos de Indios Exista por lo Menos una Distancia de Media Legua" [Royal Decree. By which it is ordered that between (Spanish) haciendas and Indian towns there should be a distance of at least half a league] (Tomar, 1 de mayo de 1581/Tomar May 1, 1581), in Cedulario de Tierras Compilación de Legislación Agraria Colonial (1497-1820), ed. Francisco de Solano (México D. F.: Universidad Nacional Autónoma de México, 1984), doc. 117, 258.

${ }^{78}$ King Charles I, “Real Cédula. Para que las Estancias de Ganados se sitúen Lejos de los Pueblos y Sementeras de los Indios" [Royal Decree. That the cattle ranches are located away from the Indian towns and their cultivated plots] (Valladolid, 24 de marzo, 1550/Valladolid, March 24, 1550), in Cedulario de Tierras Compilación de Legislación Agraria Colonial (1497-1820), ed. Francisco de Solano (México D. F.: Universidad Nacional Autónoma de México, 1984), doc. 51, 173; King Philip II, “Real Cédula. Por la que se ordena que Entre Haciendas y Pueblos de Indios Exista por lo Menos una Distancia de Media Legua" [Royal Decree. By which it is ordered that between (Spanish) haciendas and Indian towns there should be a distance of at least half a league] (Tomar, 1 de mayo de 1581/Tomar, May 1, 1581), in Cedulario de Tierras Compilación de Legislación Agraria Colonial (1497-1820), ed. Francisco de Solano. (México D. F.: Universidad Nacional Autónoma de México, 1984), doc. 117, 258.

${ }^{79}$ King Philip V, "Real Cédula. Ordenando que se cumplan las Disposiciones Dictadas sobre los Bienes y Disponibilidades de los Pueblos de Indios" [Royal Decree. Ordering that the provisions issued on the Indian assets and availability of lands compiled with the Indian peoples] (Madrid. 15 de octubre, 1713/Madrid, October 15, 1713), in Cedulario de Tierras Compilación de Legislación Agraria Colonial (1497-1820), ed. Francisco de Solano (México D. F.: Universidad Nacional Autónoma de México, 1984), doc. 196, 405-406.

${ }^{80}$ See Mörner, La Corona Española; de Solórzano y Pereyra, Política Indiana. 


\section{The Epidemiological Question}

One key question remains open in regard to the colonial paradox: were epidemics responsible for the liquidation of the majority of the population as claimed first by Jehan Vellard, in an article published in 1956 and Woodrow Borah in 1962, and later by other scholars such as Alfred Crosby, William H. McNeill, Suzanne Austin Alchon, Nicolás Sánchez Albornoz, and Noble David Cook? ${ }^{81}$ A parallel revisionist interpretation, started as early as the 1960s by Juan Friede, Stafford Poole, and John Hemming, and spearheaded since then by Benjamin Keen, Tzvetan Todorov, Carlos Sempat Assadourian, Massimo Livi Bacci, David Stannard, Tzvi Medin, Andrés Reséndez, Matthew Restall, and others rejects this claim. In their view, the extremely harsh living conditions, ethnic dehumanization, cultural annihilation, the state of living under constant threats, endless moves from one ecological region to another, and hunger and despair were the main causes for the demise of the native population. ${ }^{82}$

There is probably no way to resolve this controversy, since we do not have any reliable Spanish or Indian analyses about the cause of death among the native population during the period in question. ${ }^{83}$ Some evidence do exist, I believe, which indicates that the exceptionally high death toll has more to do with Spanish policies and behavior than epidemiological or biological reasons. The first is the challenge posed by the Caribbean case, where smallpox broke out in 1518, after most of the Indian inhabitants of this extensive region were already dead. ${ }^{84}$ Another challenge is posed by the epidemiologists themselves, who have been forced to acknowledge the Spaniards' brutality and the harmful impact of their interference in the ecological balance and the natives' way of life. For example, Suzanne Austin Alchon pointed out, in reference to the demographic disaster of sixteenth-century Ecuador, that in Spanish America, "illness was not only physiological, it was also political." ${ }^{85}$ In other words, "the introduction of Old-World infections does not fully explain the dramatic decline of native populations. Rather, the combination of epidemic diseases and the simultaneous loss of control over social and economic resources led to the death of millions." ${ }^{\prime 86}$

${ }^{81}$ Jehan Vellard, "Causas Biológicas de la Desaparición de los Indios Americanos," Boletín del Instituto Riva Agüero 2 (1956), 77-93; Woodrow Borah, "América como Modelo?: El Impacto Demográfico de la Expansión Europea Sobre el Mundo no Europeo," Cuadernos Americanos 21, no. 6 (1962), 176-185; Alfred W. Crosby, The Columbia Exchange: Biological and Cultural Consequence of 1492 (Westport: Greenwood Press, 1973), 31; Alfred W. Crosby, "Conquistador y Pestilencia: The First New World Pandemic and the Fall of the Great Indian Empires," The Hispanic American Historical Review 47, no. 3 (1967), 321-337; William H. McNeill, Plagues and Peoples (New York: Anchor Press, 1976), 102-105, 206, 227228; Suzanne Austin Alchon, Native Society and Disease in Colonial Ecuador (Cambridge: Cambridge University Press, 1991); Nicolás Sánchez Albornoz, "The Population of Colonial Spanish America," in The Cambridge History of Spanish America, II: Colonial Spanish America, ed. Leslie Bethell (Cambridge: Cambridge University Press, 1989), 8-11; Noble David Cook, Born To Die: Disease and New World Conquest, 1492-1650 (Cambridge: Cambridge University Press, 1998) Elsa Malvidi, “La Epidemiología, una Propuesta para Explicar la Despoblación Americana," Revista de Indias 63, no. 227 (2003), 21-65.

${ }^{82}$ John Hemming, The Conquest of the Inca (London: Abacus, 1972), 349-365; Benjamin Keen, "The White Legend Revisited: A Reply to Professor Hanke's 'Modest Proposal'," The Hispanic American Historical Review 51, no. 2 (1971), 336-355; Stannard, American Holocaust; Tzvetan Todorov, The Conquest of America: The Question of the Other (New York: Harper and Row, 1982), 5, 145; Juan Friede, "Demographic Changes in the Mining Community of Muzo after the Plague of 1629," The Hispanic American Historical Review 47, no. 3 (1967), 338-343; Assadourian, La Despoblación Indígena, 419-453; Massimo Livi Bacci, Conquest: The Destruction of the American Indios, trans. Carl Ipse (Cambridge and Malden: Polity Press, [2005] 2008); Tzvi Medin, Mito, Pragmatismo e Imperialismo. La Conciencia Social en la Conquista del Imperio Azteca (Madrid: Iberoamerica-Vernuert, 2009), 21-67; Reséndez, The Other Slavery, 17; Restall, When Montezuma Met Cortés, 328-330.

${ }^{83}$ At the 2008 conference of historians at Juárez University (Chihuahua) in Mexico, which focused on the historical impact of smallpox on the population of New Spain from the beginning of the colonial period until the twentieth century, conference participants admitted that it was impossible to conduct an "archeology of mortality" that could be applied to the sixteenth century. See, David Robichaux, "El Papel de la Viruela en la Historia Demográfica de México: Reflexiones a partir de Cuatro Siglos de 'Viruelas' en dos Parroquias de Tlaxcala," in El Impacto Demográfico de la Viruela en México de la época Colonial al siglo XX: Estudios de Larga Duración, vol. 3, eds. Chantal Cramaussel et al. (Zamora: El Colegio de Michoacán, 2010), 23, 32, 37-39.

${ }^{84}$ The attempt by Noble David Cook, a great advocate of the epidemic approach, to show that deadly epidemics broke out in the Caribbean even before 1518, seems to me far-fetched, since it does not include any convincing quantitative or comparative analysis. See, Cook, Born to Die, 37-59.

${ }^{85}$ Alchon, Native Society and Disease, 133.

${ }^{86} \mathrm{Ibid}$. 
This was clear enough not only to the more prominent sixteenth-century critics such as las Casas, Gonzalo Fernández de Oviedo, or Alonso de Zorita, ${ }^{87}$ but also to less well-known observers such as the delegates to the Third Provincial Council of the Mexican Church, who warned the king about the imminent danger of Indian extinction, which would lay waste to the colonial territories and put an end to the Crown's hopes for great wealth and prestige.

What seems even more convincing, however, is the fact that none of the 6,447 laws included in the 1681 compilation-more than sixty percent of which were enacted in the sixteenth centurymade any mention of pestilencias, pestes (epidemics), or contained any guidelines about dealing with outbreaks of such contagious diseases. If the laws contained no references to epidemics, it is not unreasonable to expect that at least some of the thousands of the most prominent cédulas reales (royal decrees) would deal with diseases, but my analysis of more than 1,000 such commands from the years 1500-1650 reveals that almost none of them did so. The word enfermedades (diseases) rarely appears, and when it does it is not in the sense of epidemics, but as part of a general demand addressed to the colonial authorities or the Spanish encomenderos (beneficiaries) to "treat the natives well, bring them into the bosom of Christianity, and provide them with food, clothing, and a cure for their diseases." 88

The kings and their councils were aware of the spread of epidemics, since this information was regularly reported by colonial officials, visitors, and clergy ${ }^{89}$ Yet, contrary to their active involvement in coping with the plagues that erupted in Spain during the same period, ${ }^{90}$ they showed no similar apprehension about this matter in America. ${ }^{91}$ What worried the monarchs more than the diseases was the vicious behavior of the Spanish settlers, castes, and officials towards the Indians. The complaints lodged by Spain's monarchs were not isolated comments, but rather a long-standing criticism of Spanish behavior, which cited enslavement, extortion, intimidation, human trafficking, invasion, displacement, the disruption of normal life, exhaustion, as well as rape, threats, violence, and death. The following cédula (royal command) of February 1577, addressed to the audiencia (high court) of Quito is but one example, "[b]ecause of the excessive work and abuse that they [the Spaniards] have done and still do [to the Indians], many [of them] have died." The cédulas (royal command) stated time and again that they (the Indians) "were running out (se han acabando) as the result of the Spaniards." 92

${ }^{87}$ Zorita, Life and Labor, 174-273.

${ }^{88}$ King Philip II, “Real Respuesta al Gobernador de Venezuela Sobre los Servicios Personales de Los Indios" [Royal response to the governor of Venezuela regarding the personal services of the Indians] (San Lorenzo, 27 de Julio de 1594), in Colección de Documentos Para la Historia de la Formación Social de Hispanoamérica, II, Primer Tomo, ed. Richard Konetzke (Madrid: Consejo Superior de Investigaciones Científicas, 1953-1958) doc. 10, 19.

${ }^{89}$ See, for example, Fray Toribio Benavente de Motolinía, “Carta de Fray Toribio Benavente de Motolinía al Emperador Carlos V" [Letter from Fray Toribio Benavente de Motolinía to Emperor Charles V (I)] (2 de enero de 1555), in Historia de los Indios de la Nueva España: Relación de los ritos antiguos, idolarias y sacrificios de los Indio de la Nueva España, y de la maravillosa conversión que Dios en ellos ha obrado, ed Fray Toribio Benavente de Motolinía (México: Porrúa, [1565] 1973), 216; and Bacci, Conquest, 136-143, 175-176, 187-188.

${ }^{90}$ Julián Montemayor, “Una Ciudad Frente a la Peste: Toledo a Fines del siglo XV,” En la España Medieval 7 (1985), 11131127; Alfredo Alvar Ezquerra, "Madrid Reflejo de los Problemas Sanitarios de la Península: la Peste de 1596 Vista por un Galeno de la Corte," Anales del Instituto de Estudios Madrileños 20 (1983), 203-218; Alexandra Parma Cook and Noble David Cook, The Plague Files: Crisis Management in Sixteenth-Century Seville (Baton Rouge: Louisiana State University, 2009), 70-71, 74-75, 89-91, 116-120, 263-268; Kristy Wilson Bowers, Plague and Public Health in Early Modern Seville (Rochester: University of Rochester Press, 2013), 89-99.

${ }^{91}$ Fernando de Torres y Portugal, while serving as the royal governor of Seville (1578-1583), enlisted the help of the king and his council when an influenza epidemic broke out there in 1580, but apparently did not bother to do so when a series of harmful epidemics erupted in Peru during his term as its Viceroy (1584-1589). See, Cook and Cook, The Plague Files, 270.

${ }^{92}$ King Philip II, “Real Cédula. A las Audiencias de Santa Fe de Quito para que castiguen con mucho rigor a los Españoles que vendieren o tuvieren a los Indios por Esclavos" [Royal Decree. Order the Audiences of Quito to punish with great rigor Spaniards who employ or sell Indians as slaves] (Madrid, 4 de febrero de 1577/Madrid, February 4, 1577), in Colección de Documentos Para la Historia de la Formación Social de Hispanoamérica, I, ed. Richard Konetzke. (Madrid: Consejo Superior de Investigaciones Científicas, 1953-1958), doc. 366, 501. Audiencia was a court with broad judicial and administrative authority. Audiencias were directly subordinate to the viceroy and functioned as his executive branch within a defined territorial space that contained a number of districts (corregimientos), each of which oversaw a number of municipal councils (ayuntamientos) that, in turn, oversaw larger numbers of Indian and Spanish localities. 
Over the centuries, the Crown repeatedly attributed the decimation of the native population to their agents' disregard for royal demands of sensitive and protective behavior towards the Indians. As the royal letter of November 1583 to the Audiencia of Nueva Granada notes, (the natives) "are sent exhausted to work which causes their death" (se ofrecen humildes al trabajo que se sigue su muerte). ${ }^{93}$ In May 1582, King Philip sent a cédula (royal command) to the Bishop of Antekera (today's Oaxaca City in Mexico) and noted that "the severe treatment of the encomenderos has resulted by now in a loss of one-third of them [the natives] in some regions." The cédula (royal command) also mentioned that they are looked upon as slaves, often bought and sold, beaten, or starved, and that "there are mothers who kill their children at birth, saying that they want to liberate them from the horrible tasks they would be enforced to do [as they grew older]." 94

As early as November 1533, the Colonial Council issued a document calling upon the colony's leadership to follow the principles of proper, sensitive, and humane treatment due to the Indians para que multipliquen y no se vayan acabando como hasta aquí ("so that they multiply and don't end up as occurred until now"). Nevertheless, the self-same document noted that these instructions should not necessarily be obeyed por el percepto ("as being strictly perceived") or be executed (de ejecutar) a la letra ("to the letter"). Due to the long distance from Spain, the letter went on, the governors' conscience and prudence, as well as God, would have to be their guide. ${ }^{95}$ This letter is tantamount to an official confession of royal powerlessness, an acknowledgement of the abovementioned "system of adaptation," or as Magnus Mörner put it, "non-compliance of the law as a legal institution." The culture of adaptation enabled the viceroys to endorse life-threatening actions prohibited by the kings, such as certain forms of tributo (tribute) payment, personal services (forced labor demanded by encomenderos (beneficiaries) in lieu of poll taxes, which were formally banned in 1549), child labor, etc., ${ }^{96}$ the fatal consequences of which were attested to in the reports of district officials and local church leaders. ${ }^{97}$

Thus, the Spanish monarchs, apparently accepting the seemingly inevitable human toll of the plagues, such as those that swept through Spain during the sixteenth and seventeenth centuries, ${ }^{98}$

Audiencias typically consisted of well-known senior legal experts and were headed by "presidents." The first audiencias were established in Santo Domingo (1511), Mexico City (1528), Panama (1538), Lima (1542), Guatemala (1542), New Galicia (western Mexico) (1538), and Bogotá (1549). By 1650, the Spanish had established a total of ten audiencias, four in New Spain and six in Peru. Viceroys served as the presidents of audiencias in their cities of residence. The territorial boundaries of viceroyalties and audiencias largely determined the national character of Latin America after its liberation.

${ }^{93}$ King Philip II, “Real Cédula. A la Audiencia del Nuevo Reino de Granada sobre el buen tratamiento de los indios" [Royal Decree. To the Audience of the New Kingdom of Granada on the good treatment of the Indians] (San Lorenzo, 1 de noviembre de 1583/San Lorenzo, November 1, 1583), in Colección de Documentos Para la Historia de la Formación Social de Hispanoamérica, I, ed. Richard Konetzke (Madrid: Consejo Superior de Investigaciones Científicas, 1953-1958), doc. 417, 551-552.

${ }^{94}$ King Philip II, “Real Cédula. De su Magestad en Fabor de los Indios" [Royal Decree. Of his majesty in favor of the Indians] (Lisboa, 29 de mayo de 1582/Lisboa, May 29, 1582), in Manuscritos del Concilio Tercero Provincial Mexicano (1585), ed. Alberto Carillo Càzares (Zamora y México: El Colegio de Michoacán y La Universidad Pontíficia de México, 2006), vol. II, no.1, fol. 123, 333-334. The cédula was exposed by Pedro de Pravia on May 18, 1585, during the discussion on the repartimiento issue at The Third Provisional Convention of the Mexican Church.

${ }^{95}$ Consejo de las Indias, "Memoria Breve de los Artículos que parece al Consejo que se deben de Ordenar" [Brief memorial about the issues that seem to the Council (of the Indies) that should be ordered] (Madrid, 18 de noviembre de 1533/ Madrid, November 18, 1533), in Colección de Documentos Para la Historia de la Formación Social de Hispanoamérica, I, ed. Richard Konetzke (Madrid: Consejo Superior de Investigaciones Científicas, 1953-1958), doc. 83, 150-153.

${ }^{96}$ María Trinidad Pulido Solis, “El Trabajo Indígena en la Región de Zinapecuaro-Taximaroa-Maravatío," in Michoacán en el siglo XVI (Colección Estudios Michoacanos VII), ed. Carlos Salvador Paredes Martínez et al. (Morelia: Fimax Publicistas, 1984), 311-373.

${ }^{97}$ Armando Mauricio Escobar, "Las Encomiendas en la Cuenca Lacustre de Cuitzeo," in Michoacán en el siglo XVI (Colección Estudios Mihcoacanos VII), ed. Carlos Salvador Paredes Martínez et al. (Morelia: Fimax Publicistas, 1984), 260-263, 270, 277, 295; Pulido Solis, El Trabajo Indígena, 355-356.

${ }^{98}$ If we take Seville as an example, the epidemic of 1580-1581 was moderate, causing the deaths of about 12,000 people (about 10\% of the city's population). The epidemic of 1599-1600 was more severe and resulted in a larger number of victims, probably twice as many as in the previous outbreak. See Cook and Cook, The Plague Files, 62; Kristy Wilson Bowers, Plague, Politics and Municipal Relations in Sixteenth-Century Seville (Ph.D. Diss. Submitted to the Department of History, Indiana University, December 2001), 11. 
focused their attention on the worsening human factor operating parallel to the epidemics. They had no real success, most likely as a result of the colonial paradox. Interestingly, certain areas such as Ecuador-where no mines operated-experienced a different fate. In these regions, the natives made a more rapid recovery from the disasters of the plagues and the tasks meted out by the Spanish. ${ }^{99}$ These unique conditions, enabling recovery, apparently missing in most other parts of Spanish America, ${ }^{100}$ emphasize my argument regarding the negative impact of the Crown's policy in Spanish America.

\section{What Led to the Colonial Paradox?}

Why was there such a disparity between the Crown's intentions and the chaotic reality that prevailed in the colonies? What were the reasons behind the permanent appearance of contradictory positions in the ruling monarch's protective laws and directives? I would like to suggest a number of explanations.

Following the marriage of Isabella of Castille and Ferdinand of Aragón, Spain became embroiled in internal wars over unification, conquests, and vested interests in North Africa, Sicily, southern Italy, Venice, and Milan. Moreover, it was not only deeply entangled in a struggle against the Protestants and the Turks, and repeated rebellions in the Low Countries, but it also had to contend with threats from Muslims residing in Spanish territory (primarily Valencia and Granada). In addition, Spain was also involved in major commercial and military campaigns against pirates, and the English and Dutch fleets in the Atlantic Ocean. ${ }^{101}$

In most cases, the conquests in America and elsewhere were not funded by the monarchy, but by officers and soldiers, who had received bank loans and funding from prosperous merchants, entrepreneurs, and even clergymen in the colonies and Spain, in exchange for high interest rates. Payment was made by means of war assets and via the encomiendas (grants), to which the Indians were forced to relocate. ${ }^{102}$ Furthermore, exploratory and invasive expeditions, though funded mainly by the Crown, were also sponsored by commercial and banking interests, primarily from Genoa. The annual interest rate for these loans was ten percent, with heavy penalties for undue delays in their repayment. ${ }^{103}$

The considerable challenges the Spanish monarchy was facing at home (unifying Spain and consolidating Ferdinand II's personal rule over all of Spain after the queen's death in 1504, and the rule of Charles I following Ferdinand II's death in 1516) created a chronic deficit in the Spanish treasury and an ongoing crisis over the repayment of accumulated debts. In 1574, Spain's overall debt was 80 million ducats, whereas annual revenues totaled only 5.6 to 6 million ducats (twothirds of it coming from America), and annual expenditures amounted to more than 9 million ducats. Spain was on the brink of a serious debt repayment crisis. ${ }^{104}$

Additionally, for internal political reasons, Spanish colonization was based not on the emigration of self-employed peasants and mine workers, but on relatively few immigrants (about 118,000 by

${ }^{99}$ Alchon, Native Society and Disease, 131.

${ }^{100}$ Reséndez, The Other Slavery, 45.

${ }^{101}$ Paul Stewart, "The Soldier, the Bureaucrat, and the Fiscal Records in the Army of Ferdinand and Isabella," The Hispanic American Historical Review 49, no. 2 (1969), 281-290; Murdo J. Macleod, "Spain and America: The Atlantic Trade 14921720," in The Cambridge History of Spanish America, vol. 1: Colonial Spanish America, ed. Leslie Bethell (Cambridge: Cambridge University Press, 1984), 374-379.

${ }^{102}$ Konetzke, América Latina, 34-35, 104-105, 145-147, 169; John H. Elliott, Imperial Spain 1469-1716 (London: Penguin Books, [1963] 1990), 63-65.

${ }^{103}$ Fernand Braudel, Civilization and Capitalism, 15th-18th Century, vol. 3: The Perspective of the World, trans. Sian Reynolds (Berkeley: University of California Press, 1992), 164-166.

${ }^{104}$ Albert W. Lovett, “Juan de Ovando and the Council of Finance (1573-1575)," The Historical Journal 15, no. 1 (1972), 1-5, 15; Albert W. Lovett, "The Castilian Bankruptcy of 1575," The Historical Journal 23, no. 4 (1980), 900-907; Macleod, Spain and America, 366; Earl J. Hamilton, American Treasure and the Price Revolution in Spain, 1501-1650 (New York: Octagon Books, 1965), 79-80, 195-196. Elliott, Imperial Spain, 285-293, suggests some other figures concerning the Spanish budget towards the end of the sixteenth century: Expenditures of 12 million ducats and a total income of 9.8 million ducats, of which 2 million ducats came from colonial silver. 
1572), ${ }^{105}$ who came mainly from society's middle and upper classes, and functioned as planters, cattle breeders, traders, managers, mining and sweatshop entrepreneurs, and so forth. The basis for obtaining wealth-labor-was therefore imposed on the Indians. Indeed, one of the important proposals about forced labor was put forward by Pedro de Pravia, a Dominican theologian and council advisor, during the Third Provisional Convention of the Mexican Church. He suggested that henceforth only Spanish settlers committed to working the vast lands of America with their own hands-helped solely by hired workers-would be dispatched from Spain, instead of cynical manipulators, who were only interested in filling their own pockets at the expense of the natives. ${ }^{106}$ Pravia also proposed that settlers who already resided in America and sought agricultural lands for cultivation would receive estates only if they did not subject Indians to forced labor. If the settlements did not develop this way, he warned, the growing number of newcomers from Spain and Creoles born in New Spain would lead to the final and total destruction of the indigenous population, which was already in considerable decline. ${ }^{107}$ Needless to say, the proposal remained only nominally in conference protocols.

Another reason for the colonial paradox was the mother country's decision not to consider any alternative to the extremely arrogant, exploitative, and monopolistic order it had adopted, ${ }^{108}$ which was based not only on a theoretical recognition of the indigenous peoples, but also on the fundamental liberty and sovereignty of the natives throughout America. From 1539, three propositions were presented to the Crown by well-esteemed public figures, who had witnessed the disaster in the colonies and feared that if the perception of power in America did not change, Spain would be condemned for generations.

These proposals spoke about a type of Spanish-Indian partnership, either economic (Vitoria's proposal in his De Indis lecture of 1539), ${ }_{1}^{109}$ or political (las Casas's outline presented in his essay De imperatoria seu [sive] regia potestate (The Imperial or Royal Power) of 1555 or 1556). A third suggestion, made by the Third Provisional Convention of the Mexican Church, spoke about retaining domination, but based only on free Spanish and Indian labor. Las Casas's idea of a Spanish protectorate for America was further developed by a group of theologians and friars from the Salamanca School that had formed around Vitoria during his lifetime. One member of this group was the highly respected theologian Juan de la Peña, who wrote two essays-in 1560 and 1563 respectively-on this issue. ${ }^{110}$ Another was the valiant Franciscan, Alonso de Maldonado de Buendia, who worked among the Indians of Peru and Mexico in 1551-1561. Shocked by the terrible conditions they endured, he sent a series of memorandums on the idea of a colonial protectorate to King Philip and the Council of the Indies between 1561 and 1567. ${ }^{111}$ A third figure was the wellknown theologian Juan Roa Dávila, who wrote a thoughtful essay on this theme, De regnorum iustitia (The Kingdom of Justice), which was published in $1591 .{ }^{112}$

The most straightforward proposal, which could have been seen as a first step to a more radical political resettlement of Spanish rule in America, was the one deliberated by the Third Provisional Convention of the Mexican Church. It was based on the well-planned integration of all caste members (mastizos (mixed-race inhabitants, the progeny of Spaniards and Indians), mulattos

${ }^{105}$ Elliott, Imperial Spain, 185, calls the effort to determine the number of settlers in America "a matter of guesswork."

${ }^{106}$ Cázares, ed., Manuscritos del Concilio Tercero, Tomo II, no. 1, fol. 120v, 328.

${ }^{107}$ Ibid., 120v-121r, 328-329.

${ }^{108}$ Anibal Quijano, “Coloniality of Power, Eurocentrism and Latin America," Nepantla: Views from South 1, no. 3 (2000), 533-542.

109 de Victoria, De Indis, 161-162.

110 Juan de la Peña, "La Guerra Contra Los Indios," in Juan de la Peña, De de Bello Contra Insulanos, Intervención de España en América, I, Escuela Española de la Paz, segunda generación, 1560-1585, ed. Luciano Pereña et al, vol. 9 of Corpus Hispanorum de Pace (Madrid: Consejo Superior de Investigaciones Científicas, 1982), 136-276; Juan de la Peña, "La Libertad de Los Indios Contra Sepúlveda," in Juan de la Peña, De de Bello Contra Insulanos, Intervención de España en América, I, Escuela Española de la Paz, segunda generación, 1560-1585, ed. Luciano Pereña et al, vol. 9 of Corpus Hispanorum de Pace (Madrid: Consejo Superior de Investigaciones Científicas, 1982), 277-393; Luciano Pereña, "La Escuela de Salamanca y la Duda Indiana," in Francisco de Vitoria y la Escuela de Salamanca: La Ética en la Conquiesta de América, ed. Demetrio Ramos Pérez et al., vol. 25 of Corpus Hispanorum de Pace (Madrid: Consejo Superior de Investigaciones Científicas, 1984), 306-312, 338-344.

${ }^{111}$ Alonso Maldonado, “Memorial de Agravios y Remedios a SM del Rey Don Felipe II (1565)," in Juan de la Peña, De Bello Contra Insulanos. Intervención de España en América, II, ed. Luciano Pereña et al, vol. 10 of Corpus Hispanorum de Pace (Madrid: Consejo Superior de Investigaciones Científicas, 1982), 10, 83-93.

${ }^{112}$ Juan Roa Dávila, De regnorum iustitia: O el control democrático, in Corpus Hispanorum de Pace, ed. Luciano Pereña et al, vol. 7 (Madrid: Consejo Superior de Investigaciones Científicas, 1970), 2-41. 
(mixed-race inhabitants, the progeny of Spaniards and Blacks), and free blacks) and the Spanish vagabonds (called españoles ociosos) into the colonial labor system, in addition to free Indian labor, and aimed at replacing the compulsory labor system and making it superfluous.

The Crown, which had studied these ideas closely, adopted none of them. According to Anthony Pagden, this was not surprising "since, as Vitoria himself observed, kings were, of necessity, pragmatic beings compelled to 'think from hand to mouth."'113 As Pagden pointed out, from 1520, the kings of Spain no longer felt it necessary to prove their legitimacy, and even went so far as to assume the "self-appointed role of the guardian of universal Christendom." ${ }^{114}$ In 1542, the monarchy considered dismantling the encomienda (grant) system, which frustrated royal authority in America, but it soon backed down as previously noted. With regard to the pressures to end the repartimiento/mita system ${ }^{115}$ (allocation of forced Indian labor), and adopt an alternative, free labor system, the Crown was pessimistic, as its labor laws indicate. These regulations assert that the Indians are "naturally inclined to idleness,"116 despised work, even when it benefited them, and did not take on a task unless forced to do so; ${ }^{117}$ however, the labor laws implicitly promised that if one day the Indians would adopt the modern labor mentality, forced labor-hardly an ideal means of attracting people to work in any event-would be rescinded. ${ }^{118}$

In fact, the real reason for the open-ended existence of the coercive system was that if colonial employers had to give the Indians full pay for their labor, no surplus would be left for the royal quinta (fifth). ${ }^{119}$ Thus, although the Crown considered recruiting caste members and Spanish ociosas (vagabonds) for a kind of a "compulsory hired work system," it was never implemented because it was not economically feasible and would have been resisted. Thus Spain continued to maintain its compulsory working regime, based on Indian recruits only, until the end of the colonial era (with special emphasis on Peru). ${ }^{120}$ As Nicolas Robins correctly noted, this system was "rigorously reinforced by recourse to the lash, pillory, prison, and taking family members as hostages for debts, among other means." ${ }^{121}$ Furthermore, as long as the enforced labor continued to exist, so did the incentives for human trafficking, especially in "zones of conflict or Spanish expansion," as Restall correctly pointed out, chiefly in the mining centers, which always craved cheap manpower. ${ }^{122}$ Thus the colonial paradox was fueled by ongoing demands to increase the colonial surplus, the prevention of "homesteader" immigration to America, the indefinite extension of the encomienda (grant) system, and more, while ignoring the severe molestation of the natives in the Spanish mines, sweatshops, ${ }^{123}$ fields, private homes, and communities.

${ }^{113}$ Anthony Pagden, "Dispossessing the Barbarian: The Language of Spanish Thomism and the Debate over the Property

Rights of the American Indians," in Theories of Empire, ed. Anthony Pagden (Aldershot, Hampshire and Brookfield,

Vermont: Ashgate, 1998), 159.

${ }^{114}$ Ibid., 159-160.

${ }^{115}$ Mita was the traditional name in Peru for forced labor, which the Incan kings demanded of their subjects.

${ }^{116}$ King Philip II y la Princesa Gobernadora de Valladolid, “Que en quanto al estancarse en las minas, se guarden con los Indios lo que con los Españoles" [That while working in the mines, Indians are kept safely just as the Spaniards] (Valladolid, 23 de mayo de 1559/Valladolid, May 23, 1559), in Recopilación de Leyes de los Reynos de las Indias Indias, ed. Council of the Indies (Real y Supremo Consejo de Indias) (Madrid: Consejo de la Hispanidad, [1681] 1943), Tomo II, Libro IV, Título XIX, Ley XV, 71-72.

${ }^{117}$ King Philip III, “Que se puedan repartir Indios de Mita para Labor de los Campos, Cría de Ganado, y Trabjo de las Minas" [That enforced Indian workers can be distributed for agricultuarl work, livestock farming, and mining] (Aranjuez, 26 de mayo de 1609/Aranjuez, May 26, 1609), in Recopilación de Leyes de los Reynos de las Indias, ed. Council of the Indies (Real y Supremo Consejo de Indias) (Madrid: Consejo de la Hispanidad, [1681] 1943), Tomo II, Libro VI, Título XII, Ley XIX, 290.

${ }^{118}$ Ibid., 290-291.

${ }^{119}$ Enrique Tandeter, “Forced and Free Labour in Late Colonial Potosi," Past E Present 93 (November 1981), 99-104, 110117.

${ }^{120}$ Richard L. Garner, “Long-Term Silver Mining Trends in Spanish America: A Comparative Analysis of Peru and Mexico," in Mines of Silver and Gold in the Americas, ed. Peter Bakewell (Aldershot, Hampshire and Burlington, Vermont: Ashgate, 1997), 923.

${ }^{121}$ Nicolas A. Robins, "Colonial Latin America," in The Oxford Handbook of Genocide Studies, eds. Donald Bloxham and A. Dirk Moses (New York: Oxford University Press, 2010), 309.

${ }^{122}$ Restall, When Montezuma Met Cortés, 300; Reséndez, The Other Slavery, 133.

${ }^{123}$ See, for example, the typical case of the textile obrajes (sweatshops) in the Vilcashuamán region of Peru, in Miriam Salas de Coloma, De los Obrajes de Canaria y Chincheros a las Comunidades Indígenas de Vilcashuamán. Siglo XVI (Lima: Sesator, 


\section{Was the Outcome of Spain's Colonial Paradox a Case of Genocide?}

As far as Raphaël Lemkin was concerned, Spanish colonialism was clearly genocidal. He came to this conclusion in his twenty-one-page document, which examined Spanish conduct with respect to all three categories of his 1944 definition of genocide-physical, cultural, and biological. ${ }^{124}$

Lemkin's analysis helped him crystallize his views regarding the motives of those involved in the voyages of discovery and conquest-explorers, officers, soldiers, settlers, and clergymen. He assessed a wide range of factors: the human factor, including the occupying armies and their level of morality; the Spanish protectors of the Indian population, mainly church leaders, fathers or monks, such as Montesinos and las Casas (at the beginning of his career), who faced considerable difficulties when attempting to convey their critical messages to the Council of the Indies and the Crown, and convince them of the severity of the situation; the methods of genocide, especially the encomiendas (grants)-ironically established by Isabella as an alternative to slavery and a way to protect the Indians, slavery, personal servitude, mining and pearl diving, which resulted in so many deaths; the settlers' nearly sovereign status vis-à-vis the mother country; and other dominant institutions in the colony, such as family, church, and community.

The seminal theoretical basis guiding Lemkin's observations included, primarily, the institutional infrastructure, motivations, objectives, procedures, and weaknesses that defined the colonial structure, its enterprises, and practices. Though they did not all reflect high levels of genocide per se, he maintained that they uniformly targeted people defined solely as "natives" (not as a people with a specific culture); implicitly perceived them as evil and subhuman, while condemning them for their iniquities, including cannibalism; and viewed them as unworthy of treatment as true human beings. In short, Lemkin asserted, Spanish rhetoric portrayed the indigenous population as being earmarked only for servitude, to satisfy the needs, desires, and pretenses for wealth and prestige of those invested in the colonial endeavor.

Lemkin found the colonists guilty on all counts. They succeeded in deceiving the basically decent and upstanding Spanish kings. With the help of courtiers, nobles, and even priests, they prevented the monarchs from learning what was really happening in Spanish America, kept them from reading reports sent by las Casas, and even prevented him and others like him from getting fair hearings in Spain. Since many of the colonists, certainly the senior royal officials among them, were slaveholders, "they could not be induced to enforce the royal orders against slavery and other abuses." Moreover, being desperately thirsty for gold, they endorsed and ordered brutal actions against the Indians, "and sometimes even perpetrated massacres, as we have seen."125

Yet, Lemkin's analysis is inaccurate. The kings were fully aware of what was going on in the colony and knew that their orders could not be fully implemented. las Casas had unrestricted access to the kings; his complaints were stated fully and freely, and even formed the basis of protective legislation and preventive measures. Moreover, the violation of the instructions concerning the natives was not the fault of the settlers alone. They had to be rewarded for their part in the conquest and allowed to extract as much wealth as they could in order to send the largest "fifth" possible to the Crown. It was also important to keep them placated and satisfied, lest they find convincing reasons to separate from Spain. In other words, the kings had to allow the settlers to employ the indigenous people indefinitely.

Lemkin also failed to point out the main cause of death among the natives. Neither the conquest, nor the related massacres or brutal oppression of subsequent rebellions brought about the decimation of the indigenous population, but rather the unremitting forced labor. Although he stressed the importance of this factor, he did not give it sufficient weight. Nonetheless, despite the limitations of his historical knowledge and the inaccuracies of his condemning account, Lemkin had the insight to ferret out the structural factors of Spanish colonialism and point out how their

1979), 58-65.

${ }^{124}$ Lemkin's research relied on a small number of sources, especially that of las Casas, as presented by historian, author, and literary critic Marcel Brion in his book Bartolomé de las Casas Father of the Indians (New York: Edward P. Dutton, 1929). In a more focused Spanish American study, Lemkin used a variety of history books, and exploratory and archaeological logs. See Michael A. McDonnell and Dirk Moses, "Raphaël Lemkin as Historian of Genocide in the Americas," Journal of Genocide Research 7, no. 4 (2005), 517.

${ }^{125}$ Lemkin, Spain Colonial Genocide, "The Genocidists." 
cumulative effect corresponded to the dimensions of genocide. It seems to me that this approach can help provide a more accurate picture about the reasons for the Indian disaster in Spanish America: the massive exploitation of the natives, the ideology that justified it, the suppression of the criticism that decried it, the systematic disregard of the Crown's orders that were aimed at regulating it-as well as the doublespeak and significant loopholes they contained, and the free hand given to the colonial authorities to adjust them at their discretion to meet the "manifested demands of the moment." Few guarantees remained after such adjustments were made, because, as Lemkin argued, the officials making them had economic interests of their own, and "could not be induced to enforce royal orders against slavery and other abuses." ${ }^{126}$ This is the crux of the colonial paradox, a situation that gave rise to an immanently irreconcilable contradiction between economic and political needs, on the one hand, and people's lives, on the other.

Can the absence of intention allow us to conclude that the mass destruction of the indigenous people of Spanish America is not genocide, but at most, as Guenter Lewy argues, a "crime against humanity" in keeping with Article 7 of The Rome Statute of the International Criminal Court, or a "genocide in the second degree," according to the classification developed by Ward Churchill? ${ }^{127}$ It seems to me that, as long as we look at the dynamics and historic background that generated the colonial paradox from the standpoint of intention, we would have to come to this conclusion. The intention of harming the natives, whether general, special, specific, contextual, or otherwise, ${ }^{128}$ did not exist in sixteenth-century Spanish America, certainly not in the prima facie authoritativeness needed, according to Lewy, ${ }^{129}$ for a positive ruling on the crime of genocide in the International Criminal Court (ICC), or, even a special tribunal set up for former Spanish America. Yet, if we look at the colonial paradox's effects on indigenous society through a lens other than "intent"-a politically biased concept with a multitude of interpretative problems, as David Stannard asserts, ${ }^{130}$-we may reach a different conclusion.

First, I would like to introduce the concept of "political authorization," a prerequisite for any systemic action, certainly one such as genocide, which is aimed at bringing about profound physical, cultural, or psychological damage to a large group of people and is never a random, limited, or isolated act, but rather a large-scale operation, generally the outcome of "a series of state strategies," as Marc Levene explains. ${ }^{131}$ Thus, only explicit political authorization-expressed either openly or covertly-can give rise to operational plans, mechanisms, and justifications that could enable the implementation of genocide. Such authorization did not exist in Spanish America. Instead, I suspect, there was a different kind of authorization that operated in Spanish America and enabled the settlers to harm the Indians, otherwise it would never have happened. I would like to define it as "implicit authorization," which was much more encrypted, obtrusive, and elusive, though equally effective and destructive.

The Crown apparently took the road of implicit authorization because it became trapped in America, and decided to follow an autocratic direction, rather than any of the proposed alternatives. Although the mandate for Spanish America included protective directives, all the Spanish officials and settlers there understood that they were "transparent laws, guidelines created for declarative

\footnotetext{
${ }^{126} \mathrm{Ibid}$.

${ }^{127}$ Guenter Lewy, "Can There Be Genocide without the Intent to Commit Genocide?" Journal of Genocide Research 9, no. 4 (December 2007), 661-674; Ward Churchill, A Little Matter of Genocide: Holocaust and Denial in the Americas, 1492 to the Present (San Francisco: City Lights Books, 1997), 434-435.

${ }^{128}$ Berel Lang developed the concept of the "Contextual Model of Intention," or intention that becomes evident only within the genocidal act (as opposed to an "external" or a-priori model of intention). See, Berel Lang, "Intentions, Concepts of Intention, and the 'Final Solution,"' Journal of Social Philosophy 23, no. 3 (December 1992), 105-117.

${ }^{129}$ The concept of intention is included in the definition of the UN Genocide Convention. See, Lewy, Can There Be Genocide, 661.

${ }^{130}$ Tony Barta, Norbert Finzsch and David Stannard, "Three Responses to "Can There Be Genocide without the Intent to Commit Genocide?" Journal of Genocide Research 10, no. 1 (March 2008), 130-132 accessed August 17, 2020, doi: https:// doi.org/10.1080/14623520701850955.

${ }^{131}$ Mark Levene, "The Chittagong Hill Tracts: A Case Study in the Political Economy of 'Creeping' Genocide," Third World Review 20, no. 2 (1999), 346.
} 
purposes,"132 and that no one intended to "stop violators and reward those who strictly adhered to them," as Alonso de Maldonado wrote to King Felipe in 1565. The result was, Maldonado asserted, an acknowledged compromise, which enabled a kind of indefinite indigenous slavery, a situation that was (ha sido) causa de infinitas muertes ("a direct cause of endless deaths") of the natives. ${ }^{133}$ It appears to me that these anomalies, along with the license the Crown gave its agents to interpret royal ordinances and laws, and the ban on publishing unauthorized criticism of colonial policy, support the conclusion that Spanish America became a hothouse of implicit authorization to harm the Indians. This chaotic state of affairs parallels the terms "omission" or "reckless disregard" used in the discourse on genocide (albeit terms the UN repeatedly refused to add its basic definition of genocide). ${ }^{134}$ To be sure, every institution, mission, business, settler, and inspector in Spanish America knew about, witnessed, or took part in its fatal results. ${ }^{135}$

The existence of implicit authorization was discussed in the early 1970s-though not in exactly the same terms-in the well-known dispute between Benjamin Keen and Lewis Hanke regarding the Crown's protective measures. Hanke tended to be favorably impressed by the institutional measures taken to lessen the brutality in America. ${ }^{136}$ Keen, on the other hand, was unconvinced by the declared intentions of both Crown and Church. In his opinion, the situation was not the outcome of a discrepancy between legislation and reality. Rather, it stemmed from the contradiction between the laws that served the Spanish, which were strictly applied, and the laws that presumably protected the natives and limited Spanish freedom of action, which were not enforced. ${ }^{137}$

The paradox underlying the implicit authorization to harm native Americans was shaped not only by the politics of authoritative colonial rule, but also by Spain's conceptualization of America as an asset that could be managed by bona fide officials living far away from the Crown's supervision, officials who would ensure that the asset remained eternally productive, intact, and human. This outlook stemmed from the monarchy's desperate need for revenues, clearly perceived as a weakness by local groups in America, which gave them, as John Lynch pointed out, "the leverage they wanted to make deals with bureaucrats instead of merely obeying them." ${ }^{\prime 138}$ As a result, Lynch asserted, "the colonial state remained intact, but only by diluting one of the essential qualities of a state-the power to exact obedience." 139 "Spanish America came to be administered by a system of bureaucratic compromise," and decisions were made according to the "unwritten constitution" of "informal consultation between the royal bureaucracy and the king's colonial subjects." 140

Under these circumstances, the Crown was unable to demand strict implementation of its protective instructions, or consider other modes of operation in America, not without conducting serious negotiations with royal officials and settlers, for fear of losing the entire enterprise to them. This delicate existential equilibrium had already become clear in $1542,{ }^{141}$ and perhaps as early

\footnotetext{
${ }^{132}$ Maldonado, Memorial de Agravios, 10

${ }^{133}$ Ibid., 90.

${ }^{134}$ Lewy, Can There be Genocide, 662.

${ }^{135}$ Jones argues that the regime of compulsory labor in Spanish America was a first-class genocide according to Churchill's paradigm, because it held "a high degree of specific intent." See Adam Jones, Genocide: A Comprehensive Introduction, 2nd ed. (New York Routledge, 2011), 125-126.

${ }^{136}$ Hanke's explanation was that "no European nation, however, with the possible exception of Portugal, took her Christian duty toward native peoples as seriously as Spain." See Hanke, The Spanish Struggle, 175.

${ }^{137}$ Keen, The White Legend Revisited, 336-355; Peter Gerhard, The North Frontier of New Spain (Princeton: Princeton University Press, 1982), 328, 344-348.

${ }^{138}$ John Lynch, "The Institutional Framework of Colonial Spanish America," in Government and Governance of European Empires, 1450-1800, ed. Anthony John R. Russell-Wood (Aldershot, Hampshire and Burlington, Vermont: Ashgate, 2000), 217.

${ }^{139}$ Ibid.

${ }^{140} \mathrm{Ibid}$.

${ }^{141}$ King Charles I, fearing other rebellions, such as Gonzalo Pizarro's, froze the implementation of the New Laws of 1542. The king's retreat prolonged the existence of the encomiendas (grants) from one "lifetime" (vida), as stipulated in clause 30 of the New Laws, to three vidas, and in 1607 to four vidas. The encomiendas (grants) continued to exist as long as it suited those who held them. See Charles Gibson, Spain in America (New York: Harper and Row, 1966), 60-62. There was also the fear that if King Charles I insisted on implementing the new laws, the encomenderos (beneficiaries) might
} 
as 1518, when Cortés sailed to Mexico on his big adventure without any royal authorization-a traitorous but skillfully executed move. Cortés could easily have declared himself king of a prosperous and self-contained domain of his own and become a model for future adventurers (among them his own son, Martín Cortés). ${ }^{142}$ In view of this tenuous situation, the question of the monarchy's ability to fight for the Indian cause became almost irrelevant. This was especially true as more and more Creole settlers were attaining public office. According to John Lynch, "while the Americanization of the bureaucracy may have been a victory for the Creole elites, it was a further setback for the ethnic communities and those who had to supply tribute, taxes, and labor, groups who found themselves without allies under the new alignment."143

Taken together, the heavy toll exacted from the natives in body, mind, spirit, and way of life for the purpose of maintaining the vast Spanish enterprise of capital, power, and prestige, and the unrelenting force used to preserve this equation-starting with seduction, and ending with violence and brutality when resisted-verges, I believe, on the realm of genocide. The end result of this process was the substantial decimation of the native population. Although the kings tried their best to stop it, they were foiled by the colonial paradox in which they were caught. It was this weakness that provided the fertile soil on which the implicit authorization to harm the Indians could flourish.

The Indians held no hope of physical salvation from the Church either. My research indicates that the Church had, in all earnestness, intended to save the souls of the native population, but at a very early stage of the colonial enterprise, it had been forced to relinquish the acculturation process to the encomenderos (beneficiaries), who had very little interest in Christianity, while their main focus was on cashing in their war debts, and increasing their wealth and status. ${ }^{144}$ Moreover, the Popes immediately after bestowing the right to head the patronato (colonial Church patronage) on the kings of Spain, actually lost their freedom of action. This helplessness extended to the American Church as well, as clearly demonstrated in the letter dispatched to King Philip II by all the bishops of New Spain. ${ }^{145}$ Written on October 16, 1585, at the end of the Third Provisional Convention of the Mexican Church, it severely attacked the "principal ruina y disminución de los indios" (the outright ruin and decline of the Indians), using the same phrase employed by the archbishop of Mexico, Pedro Moya de Contreras when he harshly condemned the repartimiento (forced labor) system in his January 1585 letter to King Philip. ${ }^{146}$ De Contreras's correspondence explains why he and his bishops were so determined to put an end to this painful and ruinous policy, even though they were, regrettably, unable to do so.

We ought to have commanded it by public decree and charged the consciences of the governors and audiencias [high courts]. We have not done so except by a general decree in which we represented to them how important it is for them to look to the ill treatment and harassment of these Indians, because the judgment of God awaits them. Their oppression cries before the presence of God and demands vengeance of Him. But the jurisdiction of the Church and the authority of the prelates is so oppressed and downtrodden in this realm, on the pretext that it hinders profit and that little money will be made and that the proper fidelity and vassalage of Your Majesty has been lacking, [that] it would do nothing but provoke them to hatred and rage and incur the indignation of those who, stuffed with the blood of these poor creatures, are carried forward only by their greed and their ambition to

leave America and return to Spain, bringing an end to its colonial enterprise. See Antonio Osuna Fernandez-Largo,

"Etica y Política en las Leyes de Indias del siglo XVI," Anuario de Filosofia del Derecho 8, (1991), 96.

${ }^{142}$ In 1565, in an effort to turn the encomiendas into a perpetual entity, Martín Cortés was involved in an abortive plot to kill the viceroy of New Spain and the judges of the audiencia of Mexico, and establish an independent Mexican monarchy headed by himself. See Benjamin Keen's introduction to Alonso de Zorita's book, Life and Labor, 40-41.

${ }^{143}$ Lynch, The Institutional Framework, 218-219.

${ }^{144}$ In May 1517, the deputy of the Dominican Order in Santo Domingo, Pedro de Córdoba, wrote to King Charles that the encomenderos (beneficiaries) were in urgent need of learning Christian beliefs, because "none of them know it" and as a result they are "bad examples of extravagance, violence, blasphemy, and various types of cruelty." See Medin, Mito, Pragmatism e Imperlialism, 48.

${ }^{145}$ Poole, The Church and the Repartimientos, 7.

${ }^{146}$ Ibid. 
be rich in violation of our faith and in harm to their neighbor. It would have achieved no other effect than more harm and evil because of their hardened contumacy. ${ }^{147}$

Thus "one of the most violently agitated questions of the Third Mexican Council,"148 like many other crucial matters regarding Spanish rule in America, was disregarded.

\section{Conclusion}

Raphaël Lemkin did not convince the academic community that genocide was inevitably linked to colonialism. Studies have shown that not every case of colonialism has led to acts of genocide, especially not the exploitive type of settler colonialism of Spanish America. ${ }^{149}$ Researchers could not even find a correlation between the method of pseudo colonialism or annexation instituted by the Nazis in certain regions of Poland, and the Jewish and Polish genocide that occurred independently, that is, without any connection to the annexation of Polish lands. ${ }^{150}$ Nonetheless, due to the offensive character of all settler colonialism, and the difficulty of analyzing these cases without becoming entangled in the overuse of the term genocide, alternative designations such as "indigenocide,"151 "ethnocide,"152 "genocidal moments,"153 or "relations of genocide"154 have emerged. In view of this conceptual overburdening, if not a kind of "definitional dilution," Lemkin's approach has become even more isolated.

What's more, Lemkin was apparently unable to convince academia regarding other issues, e.g., that genocide encompasses more than the perpetration of physical harm to a specific group of people targeted for annihilation, thus rendering the UN definition unsatisfactory. In his view, genocide can emerge circumstantially, and not necessarily with the parent state's authorization, that is, as an outcome of unplanned and unpredictable developments in the conduct of the colonial regime, while the parent state is pressured into approving what transpires, whether reluctantly or wholeheartedly. Moreover, it is not necessarily episodic, but can occur over time, even an extended period of time; it is not limited to the twentieth century, but has been committed throughout human history, even when the concept as such was unknown; and, finally, colonial situations could (and did) give rise to genocidal circumstances, although this did not happen everywhere. As regards Spanish American history, Lemkin never doubted that what had occurred there was in fact genocide. Thus, he did not even bother mentioning the epidemics, in contrast to what researchers, many of whom did not share his views, designated as the pivotal cause for the region's demographic demise. In this sense, Lemkin, who no doubt knew enough about the epidemics in Spanish America, seemingly concluded that they contributed less than the political actions he investigated to the great loss of human lives; therefore, he preferred to discount them in his analysis. las Casas took the same polemical stance in his Short Account. ${ }^{155}$ Ironically, but

\footnotetext{
${ }^{147}$ Ibid.

${ }^{148}$ Ibid.

${ }^{149}$ Patrick Wolfe, "Settler Colonialism and the Elimination of the Native," Journal of Genocide Research 8, no. 4 (2006), 396-397; A. Dirk Moses, "An Antipodean Genocide? The Origins of the Genocidal Moment in the Colonization of Australia," Journal of Genocide Research 2, no. 1 (2000), 92-103, and note 7, 104; McDonnell and Moses, Raphä̈l Lemkin, 522; Tony Barta, "Relations of Genocide: Land and Lives in the Colonization of Australia," in Genocide and the Modern Age: Etiology and Case Studies of Mass Death, ed. Isidor Wallimann, Michael Dobkowski, and Richard L. Rubenstein (Syracuse, NY: Syracuse University Press, 2000), 239-240, 248-249.

${ }^{150}$ Thomas Kühne, “Colonialism and the Holocaust: Continuities, Causations, and Complexities: Historiographical Review," Journal of Genocide Research 15, no. 3 (2013), 345-355.

${ }^{151}$ Raymond Evans and Bill Thorpe, "Indigenocide and the Massacre of Aboriginal History," Overland 163 (2001), 33-39; Raymond Evans, "Crime Without a Name: Colonialism and the Case for 'Indigenocide'," in Empire, Colony, Genocide: Conquest, Occupation, and Subaltern Resistance in World History, ed. Dirk Moses (New York: Berghahn Books, 2008), 140-144.

${ }^{152}$ Elazar Barkan, "Genocide of Indigenous Peoples: Rhetoric of Human Rights," in The Specter of Genocide: Mass Murder in Historical Perspective, eds. Robert Gellately and Ben Kiernan (Cambridge, UK: Cambridge University Press, 2006), 137-139.

${ }^{153}$ Moses, An Antipodean Genocide?, 92-104.

${ }^{154}$ Barta, Relations of Genocide, 239-240, 248-249.

155 de las Casas, A Short Account of the Destruction of the Indies (London: Penguin Books, 1992). See note 57.
} 
certainly in line with the colonial paradox, the Spanish kings agreed with this analysis, since the various laws and decrees they promulgated made no mention of diseases.

The testimonies on which Lemkin relied led him to conclude that the "radical accumulation"156 of the causes of oppression, and the physical, psychological, and spiritual impairment of the Indians-war, so-called "pacification," ${ }^{157}$ robbery, enslavement, exploitation, invasions, feelings of worthlessness, political delegitimization, systematic religious conversion, cultural annihilation, uprooting and displacement-overwhelmed the Indians' entire array of self-protective norms and measures, and ultimately broke their spirits. Lemkin did not succumb to simplification or syllogism. He did not avoid presenting the chaotic, tyrannical qualities of the Indian cultures, including the horrors of human sacrifice and cannibalistic feasts, or the adaptation and rehabilitation processes that they endured following their destruction. ${ }^{158} \mathrm{He}$ was able to acknowledge these aspects of the indigenous culture in spite of the destruction of the Indian population and most of its cultural infrastructures, and to separate these two aspects, because, even in cases of genocide, collaboration, adaptation, and recovery are quite common.

Lemkin grasped the enormous proportions of the human calamity that occurred in Spanish America; however, his study was empirically and methodologically too brief to support the term genocide, which he attributed to it. The present study expands Lemkin's observations, and fills in some of the gaps needed to support his claim, especially in regard to the overall human debacle in America, and the colonial paradox, the method through which it was rationalized and entrenched. Countless criticisms, testimonies, and reports from diverse corners of the colony, and the Crown's enraged response to the troubling information they contained provide powerful evidence for this analysis. Hasty "legitimization ceremonies,"159 such as the Meeting at Burgos in 1512, the Valladolid debate of 1550-1551, and in some respects even the New Laws of 1542, offer further confirmation of this argument. This is not to mention the monarchy's hasty cancellation of the "protocol for conquest," 160 as Patricia Seed termed the Requerimiento (Requirement Document) war cry, ${ }^{161}$ an appalling document that made the Indians potential enemies of Spain (and the Church), and prisoners of a just war, unless they surrendered unconditionally to the whims of subjugation, exploitation, Christianization, transfer, and so on.

This partial list of chiefly emotional steps-taken out of anger, panic, pain, or the desire to mask reality-demonstrates different aspects of the exploitation-conservation paradox in Spanish America, where these two contrasting tendencies could not be balanced. In the end, the first overtook the second. Should the catastrophic results of this paradigmatic collapse be called genocide? It seems to me that this is the best term available at the moment, because it has the capacity to encompass the entire weight of the conquest, subjugation, humiliation, and exploitation that befell the Indians, which led to their almost total extinction. It may be possible to define it as genocide "by effect," 162 as Restall did; yet, as Adam Jones correctly points out, several destructive steps taken by the Crown were nonetheless intentional. ${ }^{163}$ One case concerned the Caribes, and by extension, other peripheral, troublesome groups that were difficult to pacify. The kings allowed the enslavement of these people for an indefinite period of time. Yet, according to my findings, the most destructive example was the preservation of the repartimiento/mita system until the end

\footnotetext{
${ }^{156}$ Here, I borrow a useful concept employed frequently in a range of scientific fields such as chemistry, biology, and bacteriology.

${ }^{157}$ On the concept of "Pacification" and its uses in Spanish America see Eitan Ginzberg, The Destruction of the Indigenous Peoples of Spanish America: A Genocidal Encounter (Eastbourne: Sussex Academic Press, 2018), 88-90.

${ }^{158}$ Francis Augustus MacNutt, Fernando Cortés and the Conquest of Mexico, 1485-1547 (New York and London: G. P. Putnam's Sons, 1909), 377-381.

${ }^{159}$ Anthony Pagden, Spanish Imperialism and the Political Imagination: Studies in European and Spanish-American Social and Political Theory, 1513-1830 (New Haven: Yale University Press, 1990), 5.

${ }^{160}$ Patricia Seed, Ceremonies of Possession in Europe's Conquest of the New World, 1492-1640 (Cambridge: Cambridge University Press, 1995), 88.

${ }^{161}$ Ibid.

${ }^{162}$ Restall, When Montezuma Met Cortés, 328.

${ }^{163}$ Jones, Genocide: A Comprehensive Introduction, 125-128.
} 
of Spanish rule in America. On top of these and other implicit or explicit policies discussed in this essay, which deliberately or in effect authorized actions that endangered or shortened Indian lives, we have the plagues. Perhaps not the plagues as such, but, following Suzanne Alchon's and Andrés Reséndez's observation, the luck of having enough breathing space to recover from them.

In any event, the story of Spanish colonization in America ended sadly. American cultures were fundamentally rendered extinct. Daily life, literature, writing, ceremonies and rituals, musical compositions, the sacred pantheon of the gods, the cosmology, the family structure, the generic community, patterns of economic production and political organization were nearly all wiped out without a genuine prospect of restoration. What remained, or could be restored, is only a tiny vestige of what had been. This, I suspect, was the reason for Juan Montalvo's desperate grief.

\section{Bibliography}

Alchon, Suzanne Austin. Native Society and Disease in Colonial Ecuador. Cambridge: Cambridge University Press, 1991. Doi: 10.1017/CBO9780511529047

Álverez, Salvador. "Conquista y Encomienda en la Nueva Galicia durante la Primera Mitad del Siglo XVI: 'Bárbaros' y 'Civilizados' en las Fronteras Americanas." Relaciones 29, no. 116 (2008), 153-156.

. "La Guerra Chichimeca." In Historia del Reino de la Nueva Galicia, edited by Thomas Calvo and Aristarco Regalado, 211-259. Guadalajara: Universidad de Guadalajara, Centro Universitario de Ciencias Sociales y Humanidades, 2016.

Añoveros, Jesús María. “Carlos V y la Abolición de la Esclavitud de los Indios." Revista de Indias 60, no. 218 (2000), 57-84.

Bacci, Massimo Livi. Conquest: The Destruction of the American Indios. Translated by Carl Ipse. Cambridge and Malden: Polity Press, [2005] 2008.

Barkan, Elazar. "Genocide of Indigenous Peoples: Rhetoric of Human Rights." In The Specter of Genocide: Mass Murder in Historical Perspective, edited by Robert Gellately, and Ben Kiernan, 117-139. Cambridge: Cambridge University Press, 2006. Doi: 10.1017/ CBO9780511819674.006

Barta, Tony. "Relations of Genocide: Land and Lives in the Colonization of Australia." In Genocide and the Modern Age: Etiology and Case Studies of Mass Death, edited by Isidor Wallimann, Michael Dobkowski, and Richard L. Rubenstein, 237-252. Syracuse, NY: Syracuse University Press, 2000.

Barta, Tony, Norbert Finzsch and David Stannard. "Three Responses to 'Can There Be Genocide Without the Intent to Commit Genocide?"' Journal of Genocide Research 10, no. 1 (March 2008), 111-133. Accessed August 17, 2020. Doi: $\underline{10.1080 / 14623520701850955}$

Bautista Vilar, Juan. “El Murciano Juan López, Procurador General de Tunja y Líder de la Revuelta Neogranadina Contra las Leyes Nuevos." Revista de Indias 54, no. 202 (1994), 563-571.

Borah, Woodrow. "América como Modelo?: El Impacto Demográfico de la Expansión Europea Sobre el Mundo No Europeo." Cuadernos Americanos 21, no. 6 (1962), 176-185.

Bowers, Kristy Wilson. Plague and Public Health in Early Modern Seville. Rochester: University of Rochester Press, 2013.

--------. Plague, Politics and Municipal Relations in Sixteenth-Century Seville. Ph.D. Diss. submitted to the Department of History, Indiana University, December 2001.

Braudel, Fernand. Civilization and Capitalism, 15th-18th Century. Vol. 3: The Perspective of the World, translated by Sian Reynolds. Berkeley: University of California Press, 1992.

Brion, Marcel. Bartolomé De Father of the Indians. New York: Edward P. Dutton, 1929.

Cázares, Alberto Carrillo, ed. Manuscritos del Concilio Tercero Provincial Mexicano (1585), 4 vols. Zamora y México: El Colegio de Michoacán y La Universidad Pontíficia de México, 2006.

---------, ed. El Debate Sobre la Guerra Chichimeca, 1531-1585: Derecho y Política en la Nueva España, 2 vols. Zamora: El Colegio de Michoacán, 2000.

Charles I, King. “Real Cédula. Para que los Indios no se echen en las Minas” (Granada, 8 de diciembre de 1525. In Colección de Documentos para la Historia de la Formación Social de Hispanoamérica, I, edited by Richard Konetzke, 97-98. Madrid: Consejo Superior de Investigaciones Científicas, 1953-1958. 
. "Que las Indias Occidentales estén Siempre Unidas á la Corona de Castilla, y no se pueden Enagenar." In Recopilación de Leyes de los Reynos de las Indias, edited by In Council of the Indies (Real y Supremo Consejo de Indias), Tomo I, Libro III, Título I, Ley primera, 523. Madrid: Consejo de la Hispanidad, [1681] 1943.

. "Que los Indios sean Libres, y no Sujetos á Servidumbre" (Granada, 9 de noviembre de 1526). In Council of the Indies (Real y Supremo Consejo de Indias), Recopilación de Leyes de los Reynos de las Indias, edited by Consejo de la Hispanidad, 201, Tomo II, Libro VI, Título II, Ley I. Madrid: Consejo de la Hispanidad, [1681] 1943.

"Real Provisión. Por la que se Ordena la Creación de Pueblos con la Población Indígena Dispersa y con la que se encuentra Encomendada, Dotándoles de Tierras y Bienes," (Cigales, 21 de marzo, 1550). In Cedulario de Tierras: Compilación de legislación agraria colonial (1497-1820), edited by Francisco de Solano, 181-183. México D. F.: Universidad Nacional Autónoma de México, 1984.

. “Nuevas Leyes y Ordenanzas para la Gobernación de las Indias y buen Tratamiento y Consevación de los Indios." In Juan de la Peña, De bello Contra Insulanos. Intervencíon de España en América II, Escuela Española de la Paz, Segunda Generación, 1560-1585, Posición de la Corona, edited by Luciano Pereña et al, 102-119, vol. 10 of Corpus Hispanorum de Pace. Madrid: Consejo Superior de Investigaciones Científicas, 1982.

"Real Cédula. Para que las Estancias de ganados se sitúen Lejos de los Pueblos y Sementeras de los Indios," (Valladolid, 24 de marzo, 1550). In Cedulario de Tierras Compilación de Legislación Agraria Colonial (1497-1820), edited by Francisco de Solano, 173. México D. F.: Universidad Nacional Autónoma de México, 1984.

Charles I, King, Kings Philip II, Philip III and Philip IV. “De las Reducciones y Pueblos de Indios [1551-1648]." In Recopilación de Leyes de los Reynos de las Indias, edited by Consejo de la Hispanidad, Tomo II, Libro VI, Título III, Leyes I-XXIII, 207-212. Madrid: Consejo de la Hispanidad, [1681] 1943.

Churchill, Ward. A Little Matter of Genocide: Holocaust and Denial in the Americas, 1492 to the Present. San Francisco: City Lights Books, 1997.

Consejo de la Hispanidad. "Que los Caribes, que fueren á hacer Guerra á las Islas, se hagan Esclavos, como se ordena." In Recopilación de Leyes de los Reynos de las Indias, edited by Consejo de la Hispanidad, Tomo II, Libro VI, Título II, Ley XVIII, 204-205. Madrid: Consejo de la Hispanidad, [1681] 1943.

Consejo de las Indias. "Parecer del Consejo de las Indias de 21 de octubre de 1556 en Repuesta de Ciertos Capítulos que Su Magestad les Enbio a Consultar Desde Gante Tocante a la Perpetuidad de las Indias." In Juan de la Peña, Luciano Pereña, Escuela Española de la Paz, De Bello Contra Insulanos. Intervención de España en América, II, Escuela Española de la Paz, Segunda Generación, 1560-1585, Posición de la Corona, edited by Luciano Pereña et al, vol. 10 of Corpus Hispanorum de Pace. Madrid: Consejo Superior de Investigaciones Científicas, 1982.

. "Memoria Breve de los Artículos que parece al Consejo que se deben de Ordenar" (Madrid, 18 de noviembre de 1533. In Colección de Documentos Para la Historia de la Formación Social de Hispanoamérica, I, edited by Richard Konetzke 150-153. Madrid: Consejo Superior de Investigaciones Científicas, 1953-1958.

"Recomendaciones del Consejo de Indias Sobre la Perpetuidad en el Peru." In Juan de la Peña, De Bello Contra Insulanos. Intervención de España en América, II, Escuela Española de la Paz, Segunda Generación, 1560-1585, Posición de la Corona, edited by Luciano Pereña et al., vol. 10 of Corpus Hispanorum de Pace. Madrid: Consejo Superior de Investigaciones Científicas, 1982.

Cook, Alexandra Parma and Cook, Noble David. The Plague Files: Crisis Management in SixteenthCentury Seville. Baton Rouge: Louisiana State University, 2009.

Cook, Noble David. Born to Die: Disease and New World Conquest, 1492-1650. Cambridge: Cambridge University Press, 1998.

Crosby, Alfred W. The Columbian Exchange: Biological and Cultural Consequence of 1492. Westport: Greenwood Press, 1973. 
--------. "Conquistador y Pestilencia: The First New World Pandemic and the Fall of the Great Indian Empires." The Hispanic American Historical Review 47, no. 3 (1967), 321-337. Doi: $10.1215 / 00182168-47.3 .321$

Dávila, Juan Roa. De Regnorum Iustitia: O el Control Democrático. In Corpus Hispanorum de Pace, edited by Luciano Pereña et al, vol. 7. Madrid: Consejo Superior de Investigaciones Científicas, 1970.

de la Peña, Juan. "La Guerra Contra Los Indios." In Juan de la Peña, De de Bello Contra Insulanos, Intervención de España en América, I, Escuela Española de la Paz, Segunda Generación, 15601585, edited by. Luciano Pereña et al, 136-276, vol. 9 of Corpus Hispanorum de Pace. Madrid: Consejo Superior de Investigaciones Científicas, 1982.

. "La Libertad de Los Indios Contra Sepúlveda." In Juan de la Peña, De de Bello Contra Insulanos, Intervención de España en América, I, Escuela Española de la Paz, Segunda Generación, 15601585, edited by Luciano Pereña et al, 277-393, vol. 9 of Corpus Hispanorum de Pace. Madrid: Consejo Superior de Investigaciones Científicas, 1982.

de las Casas, Bartolomé. "De Imperatoria seu regia potestate." In Bartolomé de las Casas, De regia postestate o derecho de autodeterminación, edited by Luciano Pereña et al., 1-115, vol. 8 of Corpus Hispanorum de Pace. Madrid: Consejo Superior de Investigaciones Científicas, 1984.

de Motolinía, Fray Toribio Benavente. "Carta de Fray Toribio Benavente de Motolinía al Emperador Carlos V," (2 de enero 1555). In Historia de los Indios de la Nueva España: Relación de los Ritos Antiguos, Idolarias y Sacrificios de los Indio de la Nueva España, y de la Maravillosa Conversión que Dios en ellos ha Obrado, edited by Fray Toribio Benavente de Motolinía, 203-221. México: Porrúa, [1565] 1973.

de Remesal, Antonio. Historia General de las Indias Occidentales y Particular de la Gobernación de Chiapa y Guatemala I, no. 4. Madrid: Atlas, 1964.

de Solano, Francisco, ed. Cedulario de tierras. Compilación de Legislación Agraria Colonial (1497-1820). México D. F.: Universidad Nacional Autónoma de México, 1984.

de Solórzano y Pereyra, Juan. Política Indiana, Tomos II. Madrid and Bueno Aires: Cia. IberoAmericana de publicaciones, [1647] 1930.

de Victoria, Francisco. De Indis et de Iure Belli Relectiones. Edited by Ernest Nys. Buffalo: William S. Heim and Co., [1917] 1995.

de Zorita, Alonso. Life and Labor in Ancient Mexico: The Brief and Summary Relation of the Lords of New Spain. Translated by Benjamin Keen. New Brunswick: Rutgers University Press, [1585] 1963.

Elliott, John H. Imperial Spain 1469-1716. London: Penguin Books, [1963] 1990.

-------. "The Seizure of Overseas Territories by the European Powers." In Theories of Empire, 14501800, edited by David Armitage, 139-157. Aldershot, Hampshire and Brookfield, Vermont: Ashgate, 1998.

El Ministerio de la Vivienda. Transcripción de las Ordenanzas de Descubrimiento, Nnueva Población y Pacificación de las Indias dadas por Felipe II, el 13 de julio de 1573, en el Bosque de Segovia, según el Original que se conserva en el Archivo General de Indias de Sevilla. Madrid: El Ministerio de la Vivienda, 1973.

Escobar, Armando Mauricio. "Las Encomiendas en la Cuenca Lacustre de Cuitzeo." In Michoacán en el siglo XVI (Colección Estudios Mihcoacanos VII), edited by Carlos Salvador Paredes Martínez et al, 191-295. Morelia: Fimax Publicistas, 1984.

Evans, Raymond. "Crime Without a Name: Colonialism and the Case for 'Indigenocide'." In Empire, Colony, Genocide: Conquest, Occupation, and Subaltern Resistance in World History, edited by Dirk Moses, 133-161. New York: Berghahn Books, 2008.

Ferdinand II, King. "Real Instrucción. A Don Diego Colón, Almirante y Gobernador de las Indias" (Valladolid, 3 de mayo de 1509). In Colección de Documentos para la Historia de la Formación Social de Hispanoamérica, I, edited by Richard Konetzke, 18-20. (Madrid: Consejo Superior de Investigaciones Científicas, 1953-1958.

Ferdinand II of Aragón, King and Queen Isabella I of Castille. "Introducción al Comendador Nicolás de Ovando, Gobernador de la Islas y Tierra Firme, sobre el Modo y Manera de 
Concentrar a la Población Indígena Dispersa en Pueblos" (Alcalá de Henares, 20 de marzo y Zaragoza, 29 de marzo, 1503). In Cedulario de Tierras: Compilación de Legislación Agraria Colonial (1497-1820), edited by, Francisco de Solano, 109-110. México D. F.: Universidad Nacional Autónoma de México, 1984.

. "Instrucciones al Comendador Frey Nicolas de Ovando. Gobernador de las Islas y Tierra Firme del Mar Oceano" (Granada, 16 de septiembre de 1501). In Colección de Documentos para la Historia de la Formación Social de Hispanoamérica, 1493-1810. Volume I (1493-1592), edited by Richard Konetzke, 4-6. Madrid: Consejo Superior de Investigaciones Científicas, 1953.

Fernandez-Largo, Antonio Osuna. "Etica y Política en las Leyes de Indias del siglo XVI." Anuario de Filosofia del Derecho 8 (1991), 77-102.

Evans, Raymond and Bill Thorpe. "Indigenocide and the Massacre of Aboriginal History." Overland 163 (2001), 21-39.

Ezquerra, Alfredo Alvar. "Madrid Reflejo de los Problemas Sanitarios de la Península: la Peste de 1596 Vista por un Galeno de la Corte." Anales del Instituto de Estudios Madrileños 20 (1983), 203-218.

Friede, Juan. "Demographic Changes in the Mining Community of Muzo after the Plague of 1629." The Hispanic American Historical Review 47, no. 3 (1967), 338-343. Doi: 10.1215/00182168$\underline{47.3 .338}$

Gallo, Alfonso Garcia. "La Ley Como Fuente del Derecho en Indias en el Siglo XVI." Anuario de Historia del Derecho Español 21-22 (1951-1952), 607-730.

Gamboa, Jorge Augusto M. “La Encomienda y las Sociedades Indígenas del Nuevo Reino de Granada: El Caso de la Provincia de Pampelona (1549-1650)." Revista de Indias 64, no. 232 (2004), 749-770.

García y García, Antonio. “El Sentido de las Primeras Denuncias.” In Francisco de Vitoria y la Escuela de Salamanca: La Ética en la Conquista de América, edited by Demetrio Ramos Pérez et al., 67-72, vol 25 of Corpus Hispanorum de Pace. Madrid: Consejo Superior de Investigaciones Científicas, 1984.

Garner, Richard, L. "Long-Term Silver Mining Trends in Spanish America: A Comparative Analysis of Peru and Mexico." In Mines of Silver and Gold in the Americas, edited by Peter Bakewell, 225-935. Aldershot, Hampshire and Burlington, Vermont: Ashgate, 1997. Doi: 10.4324/9781315248875-9

Gerhard, Peter. The North Frontier of New Spain Princeton: Princeton University Press, 1982.

Gibson, Charles. Spain in America. New York: Harper and Row, 1966.

Ginzberg, Eitan. The Destruction of the Indigenous Peoples of Spanish America: A Genocidal Encounter. Eastbourne: Sussex Academic Press, 2018.

González, Angel Martín. Gobernación Espiritual de Indias. Código Ovandino. Vol. I. Guatemala: Instituto Teológico Salesiano, 1977.

Quijano, Anibal. "Coloniality of Power, Eurocentrism and Latin America." Nepantla: Views from South 1, no. 3 (2000), 533-580.

Hamilton, Earl J. American Treasure and the Price Revolution in Spain, 1501-1650. New York: Octagon Books, 1965.

Hanke, Lewis. Aristotle and the American Indians: A Study in Race Prejudice in the Modern World. Bloomington: Indiana University Press, 1970.

-. "Pope Paul III and the American Indians." The Harvard Theological Review 30, no. 2 (1937), 65-102. Doi: $10.1017 /$ S0017816000022161

---------. "The ‘Requerimiento' and Its Interpreters." Revista de Historia de América 1, no. 1 (1938), 26-28.

-------. The Spanish Struggle for Justice in the Conquest of America. Dallas, TX: Southern Methodist University Press, [1949] 2002.

Hemming, John. The Conquest of the Inca. London: Abacus, 1972.

Hernández S.J., Bartolomé. "Carta de Batolomé Hernández de la Compañía de Jesús y confesor del Virrey, a Don Juan de Ovando, Presidente del Consejo de Indias," Lima, 19 de abril 
de 1572. In José de Acosta, De procuranda indorum salute, o pacificaión y colonización, edited by Luciano Pereña et al, 642-653, vol. 23 of Corpus Hispanorum de Pace. Madrid: Consejo Superior de Investigaciones Científicas, 1984.

Hussey, Ronald D. “Text of the Laws of Burgos (1512-1513) Concerning the Treatment of the Indians." Hispanic American Historical Review 12, no. 3 (1932), 301-326. Doi: 10.1215/00182168-12.3.301

Jones, Adam. Genocide: A Comprehensive Introduction, 2nd ed. New York: Routledge, 2011. Doi: $\underline{10.4324 / 9780203846964}$

Keen, Benjamin. "The White Legend Revisited: A Reply to Professor Hanke's 'Modest Proposal'." The Hispanic American Historical Review 51, no. 2 (1971), 336-355. Doi: 10.1215/0018216851.2 .336

Konetzke, Richard. América Latina, Tomo II: La Época colonial. México: Siglo XXI, [1965] 1991.

Kühne, Thomas. "Colonialism and the Holocaust: Continuities, Causations, and Complexities: Historiographical Review." Journal of Genocide Research 15, no. 3 (2013), 345-355. Doi: $10.1080 / 14623528.2013 .821229$

Lang, Berel. "Intentions, Concepts of Intention, and the 'Final Solution."' Journal of Social Philosophy 23, no. 3 (December 1992), 105-117.

Las Casas, Bartolomé de. Historia de las Indias, 3 vols. Caracas: Imprenta Ayacucho, 1986.

-------. A Short Account of the Destruction of the Indies. London: Penguin Books, 1992.

Lemkin, Raphaël. Spain Colonial Genocide. Raphaël Lemkin Collection, P-154, Box 8, Folder 12. Boston and New York: American Jewish Historical Society, Center for Jewish History.

Levene, Mark. "The Chittagong Hill Tracts: A Case Study in the Political Economy of 'Creeping' Genocide." Third World Review 20, no. 2 (1999), 339-369. Doi: 10.1080/01436599913794

Lewy, Guenter. "Can There Be Genocide without the Intent to Commit Genocide?" Journal of Genocide Research 9, no. 4 (December 2007), 661-674. Doi: 10.1080/14623520701644457

Lloyd Mecham, J. "The Church in Colonial Spanish America." In Colonial Hispanic America, edited by A. Curtis Wilgus, 200-214. New York: Russell \& Russell, 1963.

Lovett, Anthony W. "Juan de Ovando and the Council of Finance (1573-1575)." The Historical Journal 15, no. 1 (1972), 1-21. Doi: 10.1017/S0018246X00001813

-------. "The Castilian Bankruptcy of 1575." The Historical Journal 23, no. 4 (1980), 899-911. Doi: $10.1017 /$ S0018246X00025127

Lynch, John. "The Institutional Framework of Colonial Spanish America." In Government and Governance of European Empires, 1450-1800, edited by Anthony John.R. Russell-Wood, 211225. Aldershot, Hampshire and Burlington, Vermont: Ashgate, 2000.

MacNutt, Francis Augustus. Fernando Cortes and the Conquest of Mexico, 1485-1547. New York and London: G. P. Putman's Sons, 1909.

Maldonado, Alonso. "Memorial de Agravios y Remedios a SM del Rey Don Felipe II (1565)." In Juan de la Peña, De Bello Contra Insulanos. Intervención de España en América, II, edited by Luciano Pereña et al, 83-93, vol. 10 of Corpus Hispanorum de Pace. Madrid: Consejo Superior de Investigaciones Científicas, 1982.

Malvidi, Elsa. "La Epidemiología, una Propuesta para Explicar la Despoblación Americana." Revista de Indias 63, no. 227 (2003), 21-65.

Macleod, Murdo J. "Spain and America: The Atlantic Trade 1492-1720." In The Cambridge History of Spanish America. Vol. 1: Colonial Spanish America, edited by Leslie Bethell, 341-388. Cambridge: Cambridge University Press, 1984. Doi: 10.1017/CHOL9780521232234.012

McDonnell, Michael A. and A. Dirk Moses. "Raphaël Lemkin as Historian of Genocide in the Americas." JournalofGenocideResearch7,no.4(2005),501-529.Doi:10.1080/14623520500349951

McNeill, William H. Plagues and Peoples. New York: Anchor Press, 1976.

Medin, Tzvi. Mito, Pragmatism e Imperlialismo. La Conciencia Social en la Conquista del Imperio Azteca. Madrid: Iberoamerica-Vernuert, 2009. Doi: 10.31819/9783954879144

Mira Caballos, Esteban. El indio antillano: repartimiento, encomienda y esclavitud (1492-1542). Sevilla y Bogotá: Muñoz Moya Editores, 1997.

Molina Martínez, Miguel. "La Leyenda Negra Revisitada: La Polémica Continúa." Revista Hispanoamericana 2 (2012), 1-15. 
Montemayor, Julián. "Una ciudad frente a la peste: Toledo a fines del siglo XV." En la España Medieval 7 (1985), 1113-1127.

Mörner, Magnus. La Corona Española y los Foraneos en los Pueblos de Indios de América (Estocolmo [Stockholm]: Almqvist and Wiksell, 1970).

Moses, A. Dirk. "An Antipodean Genocide?: The Origins of the Genocidal Moment in the Colonization of Australia." Journal of Genocide Research 2, no. 1 (2000), 92-103. Doi: $10.1080 / 146235200112427$

Pagden, Anthony. "Dispossessing the Barbarian: The Language of Spanish Thomism and the Debate over the Property Rights of the American Indians." In Theories of Empire, 14501800, edited by David Armitage, 159-178. Aldershot, Hampshire and Brookfield, Vermont: Ashgate, 1998.

---------, trans and ed. Hernán Cortés: Letters from Mexico. New Haven and London: Yale University Press, 1986.

-------. Spanish Imperialism and the Political Imagination: Studies in European and Spanish-American Social and Political Theory, 1513-1830. New Haven: Yale University Press, 1990.

Pereña, Luciano. "La Escuela de Salamanca y la Duda Indiana." In Francisco de Vitoria y la Escuela de Salamanca: La Ética en la Conquiesta de América, edited by Demetrio Ramos Pérez et al., 291-344, vol. 25 of Corpus Hispanorum de Pace. Madrid: Consejo Superior de Investigaciones Científicas, 1984.

--------. "Estudio preliminar." In Bartolomé de las Casas, De regia Postestate o Derecho deAutodeterminación, edited by Luciano Pereña et al., ix-clvii, vol. 8 of Corpus Hispanorum de Pace. Madrid: Consejo Superior de Investigaciones Científicas, 1969.

Philip II, King. "Real Cédula. A la Audiencia de Guatemala, Ordenando se haga Justicia en Ciertas Usurpaciones de Tierras Baldíos y Edjidos en Términos de Santiago de Guatemala" (El Escorial, 10 de marzo, 1566). In Cedulario de Tierras Compilación de Legislación Agraria colonial (1497-1820), edited by Francisco de Solano, 204-205. México D. F.: Universidad Nacional Autónoma de México, 1984.

. "Real Respuesta al Gobernador de Venezuela Sobre los Servicios Personales de Los Indios" (San Lorenzo, 27 de Julio de 1594). In Colección de Documentos Para la Historia de la Formación Social de Hispanoamérica, II, Primer Tomo, edited by Richard Konetzke, 19. Madrid: Consejo Superior de Investigaciones Científicas, 1953-1958.

"Real Cédula. Por la que se ordena que entre Haciendas y Pueblos de Indios Exista por lo Menos una Distancia de Media Legua" (Tomar, 1 de mayo de 1581). In Cedulario de tierras Compilación de Legislación Agraria Colonial (1497-1820), edited by Francisco de Solano, 258. México D. F.: Universidad Nacional Autónoma de México, 1984.

"Real Cédula. Al Virrey y Audiencia de México Ampliando a 600 Varas a la Redonda los Términos del Pueblo de Indios y a 1,100 Varas los Límites de Fujación de las Estancias..." (Madrid, Junio 4 de 1687). In Cedulario de Tierras Compilación de Legislación Agraria Colonial (1497-1820), edited by Francisco de Solano 365-367. México D. F.: Universidad Nacional Autónoma de México, 1984.

. "Real Cédula. A la Audiencia del Nuevo Reino de Granada sobre el buen Tatamiento de los Indios" (San Lorenzo, 1 de noviembre de 1583). In Colección de Documentos Para la Historia de la Formación Social de Hispanoamérica, I, edited by Richard Konetzke, 551-552. Madrid: Consejo Superior de Investigaciones Científicas, 1953-1958.

"Real Cédula. A las Audiencias de Santa Fe de Quito para que Castiguen con mucho Rigor a los Españoles que Vendieren o Tuvieren a los Indios por Esclavos" (Madrid, 4 de febrero de 1577). In Colección de Documentos Para la Historia de la Formación Social de Hispanoamérica, I, edited by Richard Konetzke, 501-502. Madrid: Consejo Superior de Investigaciones Científicas, 1953-1958.

. "Real Cédula. De su Magestad en Fabor de los Indios," (Lisboa, 29 de mayo de 1582). In Manuscritos del Concilio Tercero Provincial Mexicano (1585), edited by Alberto Carillo Càzares, vol. II, no.1, fol. 123, 333-334. Zamora y México: El Colegio de Michoacán y La Universidad Pontíficia de México, 2006. 
. "Que ningun Descubrimiento, ni Poblacion se haga á Costa del Rey" (Segovia, 13 de julio de 1573). In Recopilación de Leyes de los Reynos de las Indias, edited by Council of the Indies (Real y Supremo Consejo de Indias), Tomo II, Libro IV, Título I, Ley XVII, 4. Madrid: Consejo de la Hispanidad, [1681] 1943.

- "Que á los Indios Reducidos no se quiten las Tierras que ántes Hubieren Tenido" (Toledo, 19 de Febrero de 1560). In Recopilación de Leyes de los Reynos de las Indias, edited by Consejo de la Hispanidad, Tomo II, LibroVI, Título III, Ley IX, 209. Madrid: Consejo de la Hispanidad, [1681] 1943.

Philip II, King y la Princesa Gobernadora de Valladolid. “Que en Quanto al Estancarse en las Minas, se guarden con los Indios lo que con los Españoles" (Valladolid, 23 de mayo de 1559). In Recopilación de Leyes de los Reynos de las Indias Indias, edited by Council of the Indies (Real y Supremo Consejo de Indias), Tomo II, Libro IV, Título XIX, Ley XV, 71-72. Madrid: Consejo de la Hispanidad, [1681] 1943.

Philip III, King. “Que se puedan Repartir Indios de Mita para Labor de los Campos, Cría de Ganado, y Trabjo de las Minas" (Aranjuez, 26 de mayo de 1609). In Recopilación de Leyes de los Reynos de las Indias, edited by Council of the Indies (Real y Supremo Consejo de Indias), Tomo II, Libro VI, Título XII, Ley XIX, 290-291. Madrid: Consejo de la Hispanidad, [1681] 1943.

Philip V, King. "Real Cédula. Ordenando que se cumplan las Disposiciones Dictadas sobre los Bienes y Disponibilidades de los Pueblos de Indios" (Madrid. 15 de octubre, 1713). In Cedulario de Tierras Compilación de Legislación Agraria Colonial (1497-1820), edited by Francisco de Solano, 405-406. México D. F.: Universidad Nacional Autónoma de México, 1984.

Poole, Stafford. "The Church and the Repartimientos in the Light of the Third Mexican Council, 1585." The Americas XX (1963), 3-36. Doi: $10.2307 / 979670$

--------. "Historia de los Manuscritos Conciliares." In Manuscritos del Concilio Tercero Provincial Mexicano (1585), edited by Alberto Carrillo Cázares, cii-cvii. Zamora y México: El Colegio de Michoacán y La Universidad Pontíficia de México, 2006.

---------. Pedro Moya de Contreras: Catholic Reform and Royal Power in New Spain, 1571-1591. Berkeley: University of California Press, 1987.

Powell, Philip Wayne. Soldiers, Indians and Silver: The Northward Advance of New Spain, 1550-1600. Berkeley: University of California Press, 1952.

Pulido Solis, María Trinidad. "El Trabajo Indígena en la Región de Zinapecuaro-TaximaroaMaravatío." In Michoacán en el siglo XVI (Colección Estudios Michoacanos VII), edited by Carlos Salvador Paredes Martínez et al., 297-373. Morelia: Fimax Publicistas, 1984.

Reséndez, Andrés. The Other Slavery: The Uncovered Story of Indian Enslavement in America. Boston and New York: Houghton Mifflin Harcourt, 2016.

Restall, Matthew. When Montezuma Met Cortés. The True Story of the Meeting that Changed History. New York: HarperCollins, 2018.

Robichaux, David. “El Papel de la Viruela en la Historia Demográfica de México: Reflexiones a partir de Cuatro Siglos de 'Viruelas' en dos Parroquias de Tlaxcala." In El Impacto Demográfico de la Viruela en México de la época Colonial al siglo XX: Estudios de Larga Duración, vol. 3, edited by Chantal Cramaussel et al., 21-40. Zamora: El Colegio de Michoacán, 2010.

Robins, Nicolas A. "Colonial Latin America." In The Oxford Handbook of Genocide Studies. Edited by Donald Bloxham and A. Dirk Moses, 301-321. New York: Oxford University Press, 2010.

Rosenblat, Ángel. La Población Indígena y el Mestizaje en América: Tomo I: La Población Indígena, 14921950. Buenos Aires: Editorial Nova, 1954.

Sacoto, Antonio. El indio en el Ensayo de la América Española. Quito: Universidad Andina Simón Bolívar, 1994.

Salas de Coloma, Miriam. De los Obrajes de Canaria y Chincheros a las Comunidades Indígenas de Vilcashuamán. Siglo XVI. Lima: Sesator, 1979.

Sánchez Albornoz, Nicolás. "The Population of Colonial Spanish America." In The Cambridge History of Spanish America II: Colonial Spanish America, edited by Leslie Bethell, 3-35. Cambridge: Cambridge University Press, 1989. 
Seed, Patricia. “'Are These Not Also Men?' The Indians' Humanity and Capacity for Spanish Civilisation." Journal of Spanish American Studies 25, no. 3 (1993), 629-652. Doi: 10.1017/ $\underline{\text { S0022216X00006696 }}$

-------. Ceremonies of Possession in Europe's Conquest of the New World, 1492-1640. Cambridge: Cambridge University Press, 1995.

Sempat Assadourian, Carlos. “La Despoblación Indígena en Perù y Nueva España durante el siglo XVI y la Formación de la Economía Colonial." Historia Mexicana 38 (1989), 419-454.

Sotelo, Rafael Diego Fernández. "Mito y Realidad en las Leyes de Población de Indias." In Recopilación de Leyes de los reynos de las Indias. Estudio histórico-juridicos. Edited by Francisco de Icaza Dufour, 161-255. México: Porrúa, 1987.

Stannard, David E. American Holocaust: Columbus and the Conquest of the New World. New York \& Oxford: Oxford University Press, 1992.

Stewart, Paul. "The Soldier, the Bureaucrat, and the Fiscal Records in the Army of Ferdinand and Isabella." The Hispanic American Historical Review 49, no. 2 (1969), 281-290. Doi: $10.2307 / 2510822$

Stone, Erin. “Slave Raiders Vs. Friars: Tierra Firme, 1513-1522.” The Americas 74, no. 2 (April 2017), 139-170. Doi: $10.1017 /$ tam.2017.10

Tandeter, Enrique. "Forced and Free Labour in Late Colonial Potosi." Past E Present 93 (November 1981), 98-136. Doi: $10.1093 /$ past/93.1.98

Todorov, Tzvetan. The Conquest of America: The Question of the Other. New York: Harper and Row, 1982.

Vellard, Jehan. "Causas Biológicas de la Desaparición de los Indios Americanos." Boletín del Instituto Riva Agüero 2 (1956), 77-93.

Wolfe, Patrick. "Settler Colonialism and the Elimination of the Native." Journal of Genocide Research 8, no. 4 (2006), 387-409. Doi: 10.1080/14623520601056240

Zavala, Silvio. New Viewpoints on the Spanish Colonization of America. New York: Russel and Russel, 1968.

--------. “Nuño de Guzmán y la Esclavitud de los Indios.” Historia Mexicana 1, no. 3 (1952), 411-428. 